University of Rhode Island

DigitalCommons@URI

Open Access Master's Theses

2013

\title{
Characterizing the Spread and Impacts of the Invasive Colonial Tunicate Didemnum Vexillum on Georges Bank
}

Nicole L. Lengyel

University of Rhode Island, snicker4998@yahoo.com

Follow this and additional works at: https://digitalcommons.uri.edu/theses

\section{Recommended Citation}

Lengyel, Nicole L., "Characterizing the Spread and Impacts of the Invasive Colonial Tunicate Didemnum Vexillum on Georges Bank" (2013). Open Access Master's Theses. Paper 24.

https://digitalcommons.uri.edu/theses/24

This Thesis is brought to you for free and open access by DigitalCommons@URI. It has been accepted for inclusion in Open Access Master's Theses by an authorized administrator of DigitalCommons@URI. For more information, please contact digitalcommons-group@uri.edu. 
CHARACTERIZING THE SPREAD AND IMPACTS OF THE INVASIVE COLONIAL TUNICATE DIDEMNUM

VEXILLUM ON GEORGES BANK

BY

NICOLE L. LENGYEL

A THESIS SUBMITTED IN PARTIAL FULFILLMENT OF THE

REQUIREMENTS FOR THE DEGREE OF

MASTER OF SCIENCE

IN

OCEANOGRAPHY

UNIVERSITY OF RHODE ISLAND 


\section{MASTER OF SCIENCE THESIS}

OF

NICOLE L. LENGYEL

\section{APPROVED:}

Thesis Committee:

Major Professor Jeremy S. Collie

David C. Smith

David A. Bengtson

Nasser H. Zawia DEAN OF THE GRADUATE SCHOOL 


\begin{abstract}
Since the discovery of the invasive tunicate Didemnum vexillum on Georges Bank in 2002, scientists have been investigating its spread and potential impacts on the benthic community. Previous research on the invasion of Didemnum vexillum on Georges Bank found that since its introduction, it has colonized at least $230 \mathrm{~km}^{12}$ of pebble gravel habitat in two adjacent areas with contrasting levels of bottom fishing disturbance, Area 18 (open to fishing) and Area 19 (closed to fishing). The aim of the present study is to better understand the impacts of the colonization of Didemnum vexillum to the benthic community on Georges Bank, and to investigate the potential role of bottom fishing disturbance. To accomplish this, two types of sampling were conducted: still photographs to quantify attached epifauna, including Didemnum vexillum, and Naturalist dredge samples to quantify free-living epifaunal taxa. The USGS SEAbed Observation and Sampling System (SEABOSS) was used on annual research cruises to take still photographs of the ocean bottom on Georges Bank in Area 18 from 1994-2000 and 2003-2004, and in both Areas 18 and 19 from 20062007. Bottom photos were analyzed with either a grid cell method or with a Matlab random point program. Naturalist dredge samples were collected from Area 18 from 1996-2008 and from Area 19 from 2005-2008. Analyses to investigate the long-term effects of the invasion of Didemnum vexillum in Area 18 revealed a significant increase in the percent cover of Didemnum vexillum after the infestation (2002-2008) versus before the infestation (1994-2001). A significant negative relationship was found to exist between the frequency of free-living macrofauna and the percent cover of Didemnum vexillum; as the percent cover of Didemnum vexillum increases, the
\end{abstract}


frequency of macrofauna decreases. Naturalist dredge abundance data revealed a distinct difference in the species composition before the infestation compared to after the infestation. The significant increase in the abundance of two polychaete species, Nereis zonata and Harmothoe extenuata was found to be responsible for this change.

Analyses used to investigate the potential role of bottom fishing disturbance revealed significant differences in the percent cover of colonial epifauna in Area 19 compared with Area 18. Didemnum vexillum and Filograna implexa both had a higher percent cover in Area 19 while hydroid and bushy bryozoans had a higher percent cover in Area 18. A significantly higher abundance of free-living macrofauna was observed in Area 18 compared to Area 19. Analysis of Naturalist dredge samples confirmed that there was a significant difference in species composition in Area 18 compared to Area 19, and the two species that were identified for being largely responsible for this change were Nereis zonata and Urticina felina.

The results of this study show that the invasion of Didemnum vexillum has had significant impacts on the benthic community of Georges Bank. While the tunicate appears to be negatively impacting free-living macrofauna, it may be positively impacting two polychaete species, Nereis zonata and Harmothoe extenuata by offering them protection from predation by bottom feeders. Additionally, bottom fishing disturbance in Area 18, also appears to be significantly impacting the benthic community with the fragile and structurally complex polychaete Filograna implexa, the most negatively impacted. 


\section{ACKNOWLEDGMENTS}

First and foremost I would like thank my major advisor, Dr. Jeremy Collie, for the continued support and guidance he has given to me during my time at the Graduate School of Oceanography. Dr. Collie gave me a tremendous opportunity when he hired me to work in his fisheries and benthic ecology laboratory, and again when he encouraged me to pursue a master's degree in oceanography. He has provided me with a vast amount of training, knowledge and experience that has allowed me to be where I am today as a Principal Biologist for the RI Department of Environmental Management.

I would like to give a special thanks to Dr. David Smith for the advice and guidance he has provided to me over the years. Additionally, Dr. Smith took the time to provide me with knowledge and training in the field of molecular biology and permitted me use of his laboratory. I also give thanks to committee member Dr. David Bengtson and defense chair Dr. Graham Forrester.

The National Marine Fisheries Service provided ship time on board several of its research vessels, which made collecting the data presented here possible. Page Valentine and Dann Blackwood of the U.S. Geological Survey provided the bottom photographs used in this research. Rich Bell not only created the program used to analyze the bottom photographs but was a valued office mate during my time as a graduate student. I would also like to thank several former members of the Collie Lab including Rebecca Asch, Kiersten Curti, and Brian Smith for the roles they played in my graduate coursework and research. This research would not be possible without funding provided by the National Sea Grant Invasive Species Research Program. 
Lastly, I would like to give thanks to my many friends, family members, and co-workers who have all provided me with advice and support over the years. 


\section{TABLE OF CONTENTS}

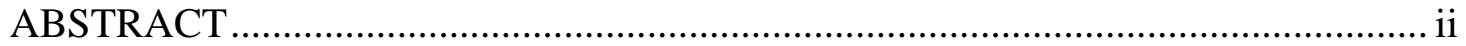

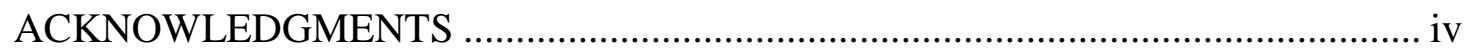

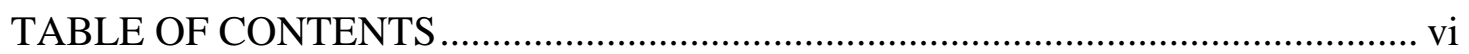

LIST OF TABLES ……................................................................................. vii

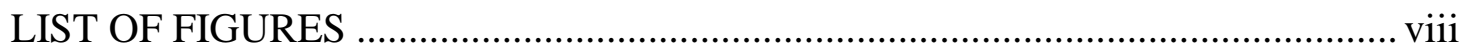

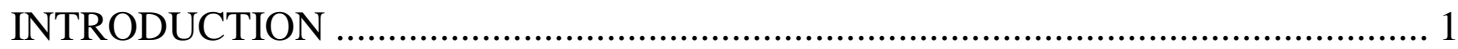

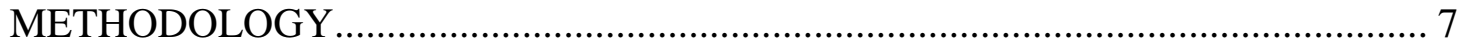

Video and Photographic Imagery ................................................................ 7

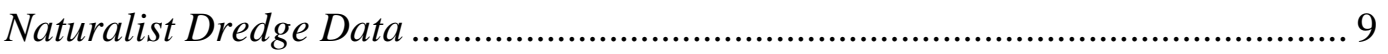

Comparison of Photographic Analysis Methods ................................................... 10

Spatial Autocorrelation Analysis ...................................................................... 11

Impact of D. vexillum on the Benthic Community .............................................. 13

Impact of Bottom Fishing Disturbance on D. vexillum ....................................... 14

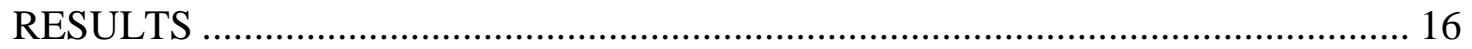

Comparison of Photographic Analysis Methods …………………………........ 16

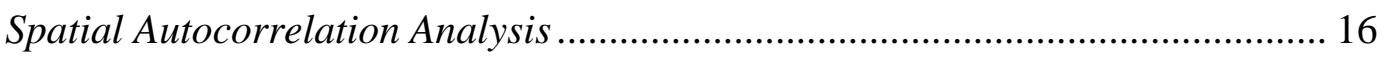

Impact of D. vexillum on the Benthic Community ................................................ 16

Impact of Bottom Fishing Disturbance on D. vexillum ..................................... 18

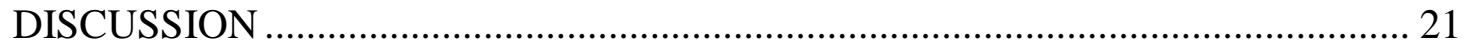

Impact of D. vexillum on the Benthic Community ............................................... 21

Impact of Bottom Fishing Disturbance on D. vexillum ...................................... 23

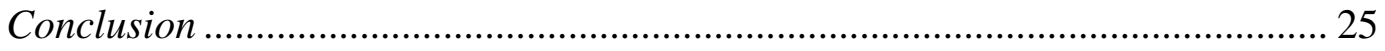

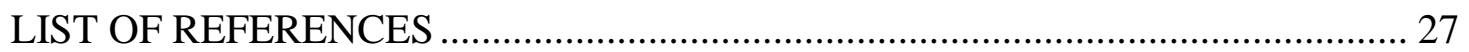

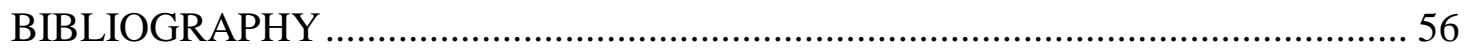




\section{LIST OF TABLES}

TABLE

PAGE

Table 1. Description of study sites on northern Georges Bank ............................... 30

Table 2. Number of photographs analyzed in Areas 18 and 19 .............................. 31

Table 3. Number of photographs that each colonial epifauna taxon is identified in for

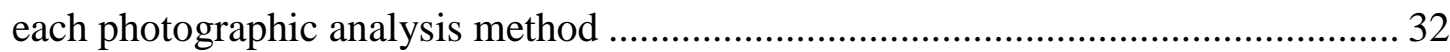

Table 4. Percent cover of colonial epifauna estimated with grid-cell method by RA

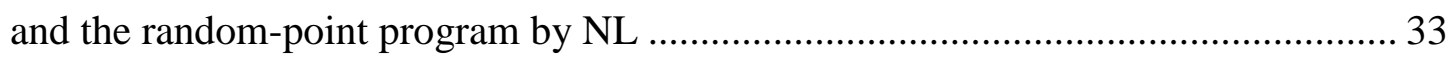

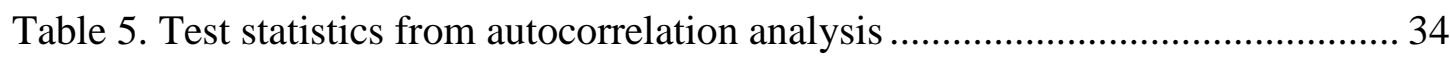

Table 6. GLM output showing the relationship between the percent cover of colonial

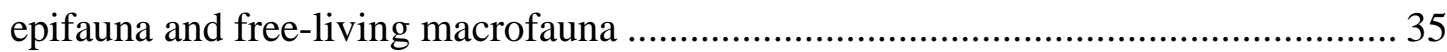

Table 7. Nested ANOVA output showing the significant difference of two polychaete species in Area 18 before (1994-2001) and after (2002-2008) the invasion of $D$.

vexillum 36

Table 8. Two-way ANOVA output showing the significant increase in abundance of two polychaete species after the infestation of $D$. vexillum in two areas with $D$. vexillum present compared to reference areas without $D$. vexillum

Table 9. Two-way ANOVA output revealing the differences in percent cover of colonial epifauna between Areas 18 and 19

Table 10. Two-way ANOVA output showing the significant increase in abundance of two species after the infestation of D. vexillum in Area 18 versus Area 19 


\section{LIST OF FIGURES}

FIGURE

PAGE

Figure 1. Study sites on Georges Bank.

40

Figure 2. Screen shot of the Mathworks Matlab R2006a program used to analyze

bottom photographs for the random-point method.

Figure 3. Variogram showing the distance at which autocorrelation exists among photographs

Figure 4. Percent cover of colonial epifauna taxa over time.

Figure 5. Relationship between the percent cover of D. vexillum and frequency of freeliving macrofauna.

Figure 6. Relationship between the percent cover of $F$. implexa and frequency of free-

living macrofauna.... 45

Figure 7. Relationship between the percent cover of hydroid and frequency of freeliving macrofauna....

Figure 8. Relationship between the percent cover of sponge and frequency of freeliving macrofauna.

Figure 9. Non-metric Multi-Dimensional Scaling (MDS) plot based on the abundance data of 97 species in Naturalist dredge samples from Area 18 (open to fishing) and Area 19 (closed to fishing) 48

Figure 10. Number per liter of sediment of two polychaete species Harmothoe extenuata (a) and Nereis zonata (b) collected in Naturalist dredge samples from Areas 18 and 19 colonized by $D$. vexillum and Areas 17 and $17 \mathrm{~W}$ not colonized by $D$. vexillum

Figure 11. Percent cover of colonial epifauna in Areas 18 and 19 after the infestation of $D$. vexillum 50

Figure 12. Non-metric Multi-Dimensional Scaling (MDS) plot showing the abundance of 18 benthic macrofaunal taxa in 82 photographic transects from Areas 18 and 19 in 2006 and 2007

Figure 13. Non-metric MDS plot showing the abundance of 18 benthic macrofaunal taxa in 82 photographic transects from Areas 18 and 19 in 2006 and 2007 
Figure 14. Non-metric MDS plot showing the abundance of 18 benthic macrofaunal taxa in 82 photographic transects from Areas 18 and 19 in 2006 and 2007

Figure 15. Non-metric MDS plot showing the abundance of 18 benthic macrofaunal taxa in 82 photographic transects from Areas 18 and 19 in 2006 and 2007 54

Figure 16. Non-metric Multi-Dimensional Scaling (MDS) plot based on the abundance data of 91 species in Naturalist dredge samples from Area 18 (open to fishing) and Area 19 (closed to fishing) after the invasion of D. vexillum (2005-2008) 55 


\section{INTRODUCTION}

Invasive species are typically described as species that spread beyond their native habitat, and become established and abundant in a new environment. Additionally, many invasive species definitions describe the species as having a negative impact, whether it is environmental or economic (Lodge et al. 2006). Many different terms exist, and subsequently definitions, to describe species that are found outside of their native range and/or environment. These terms include exotic, nonnative, non-indigenous, alien, and lastly invasive. The term "invasive" will be used throughout the thesis.

When studying invasive species, researchers often attempt to first identify the vector responsible for the introduction. Identifying the pathway of introduction can be a difficult task given the multitude of vectors that exist and are responsible for both intentional and non-intentional introductions. Some of these vectors include intentional introductions of species to be used as biological controls or in the aquarium trade industry, and unintentional introductions through mariculture, ballast water and hull fouling (Bax et al. 2003). Unintentional introductions, and the negative impacts associated with them, are the major focus of current research being conducted on invasive species. One such species is the colonial tunicate Didemnum vexillum.

Didemnum vexillum is an invasive colonial tunicate that can be quite variable in morphological appearance. Colonies can appear beige, white, pink, or yellow in color and produce small encrusting patches, large dense mats, or long protruding tendrils (Valentine et al. 2007a). Due to this high variability, taxonomic identification proved difficult. As a result, scientists turned to genetics to determine the true identity 
of Didemnum sp. samples collected from all over the world that were thought to be the same species. Genetic analysis proved that samples collected from Japan, New Zealand, the United Kingdom, Ireland, northwestern Europe and both coasts of North America were all the same species of Didemnum, specifically Didemnum vexillum (Kott 2002; Stephaniak 2009).

Typically thought to be a coastal invader, the first offshore occurrence of $D$. vexillum was documented in 2002 on Georges Bank. Prior to this, D. vexillum was commonly found in shallow coastal areas such as docks and pilings in marinas. Other substrates this invasive has been found to colonize include rock, shell, plastic, wood, and metal (Valentine et al. 2007a; 2007b). Its ability to colonize a wide variety of substrates also makes this tunicate a fierce competitor for space. Didemnum vexillum not only colonizes natural and artificial substrate but overgrows other colonial and solitary tunicates as well as mussels, sea scallops, barnacles, and other colonial epifauna.

The ability of this tunicate to colonize a variety of substrates and compete for space is not the only factor thought to be responsible for the rapid expansion of this species. The ability of $D$. vexillum to reproduce through both sexual and asexual reproduction is thought to contribute a great deal to the rapid expansion of this species. Sexual reproduction occurs through the brooding of larvae within the tunic and then the subsequent release of larvae into the environment to settle on and colonize new sites. Larvae are capable of swimming for hours before settling on suitable habitat. In areas with strong tidal flows, larvae could be transported a considerable distance before settlement occurs. Asexual reproduction through budding or fragmentation 
occurs when fragments of an existing colony break away or are pinched off and are then free to reattach and grow in a new location (Bullard et al. 2007; Valentine et al. 2009). This mode of spreading can be of particular concern in marinas, where $D$. vexillum can colonize the hull of a ship and then break off in fragments from the hull while the vessel is in transit or docks in another location. This is one of the hypotheses for the global expansion of this species.

Due to its rapid global expansion, $D$. vexillum has been the subject of a vast array of research looking to document the impacts of the tunicate in the different environments it has colonized. Valentine et al. (2007b) reported that $D$. vexillum was present in two areas of pebble/gravel habitat covering an area of $230 \mathrm{~km}^{2}$ on Georges Bank. Subsequent research on Georges Bank has shown significant impacts on the benthic species composition in two areas of pebble/gravel habitat colonized by $D$. vexillum compared to reference areas without the tunicate. This shift in species composition was found to be due to a significant increase of two polychaete species in areas with D. vexillum present (Lengyel et al. 2009). Similarly, research conducted on Long Island Sound, New York, USA indicated that within tunicate mats total abundance and species richness were either not different or significantly higher compared to outside tunicate mats. Additionally, subtle shifts in community structure were observed with the presence of tunicate mats (Mercer et al. 2009). Research has also shown however that $D$. vexillum can have many negative impacts. Morris et al. (2009) demonstrated that $D$. vexillum is capable of deterring the settlement of bay scallop larvae, which may also have significant effects on recruitment to the adult population. By extension these findings suggest that $D$. vexillum could also affect 
settlement and recruitment for sea scallops on Georges Bank (Morris et al. 2009).

Lengyel et al. (2009) also suggested that $D$. vexillum could negatively impact juvenile Atlantic cod and haddock, two species that use the pebble/gravel substrate of Georges Bank during important stages in their life cycles.

Georges Bank is part of a chain of banks extending from the Grand Banks of Newfoundland to Nantucket Shoals and measures $150 \mathrm{~km}$ wide and $280 \mathrm{~km}$ long (Uchupi and Austin 1987). Lying inside the 100-m isobath, the total area of the bank is $\sim 33,700 \mathrm{~km}^{2}$, equivalent to the states of Rhode Island, Connecticut, and Massachusetts combined (Backus 1987). Georges Bank has served as an important commercial fishing ground dating back to the $18^{\text {th }}$ century with the establishment of fisheries for several species of whales and for Atlantic cod. The groundfish fishery on the bank continued to expand as inshore grounds were depleted and fishermen began to travel farther distances to target species such as haddock, mackerel, and halibut. With the introduction of new fishing technologies such as jigging, purse seining and otter trawling, harvesting of groundfish on the bank continued to increase into the twentieth century (German 1987). In the mid 1930s the scallop fishery began to take off on Georges Bank. Soon after, the scallop beds on the bank became one of the highest valued fisheries for both the United States and Canada (Hennemuth and Rockwell 1987). As distant water fleets moved onto the bank and advances in fishing technology continued, managers adopted many management strategies including gear restrictions and seasonal area closures to address overfishing of groundfish and other resources. Even with these measures in place, stocks continued to decline and as a result, in December 1994, the Nantucket Lightship area and Closed Areas I and II on 
Georges Bank were closed to all fishing gears with the ability to retain groundfish. The closure of these three areas not only protected important habitat for species such as cod, haddock, yellowtail flounder and sea scallops, but provided researchers with a unique opportunity to investigate the effects of bottom fishing disturbance through comparative work between areas open to fishing and those closed to fishing (Murawski et al. 2000).

Bottom fishing to harvest fishery resources has been heavily criticized over the years due to the potential damage it may cause to the environment. Particular concerns include the capture of non-target species, or bycatch, the capture of undersized fish, and the damage the gear causes to the benthic environment. Scraping or ploughing, sediment resuspension or direct physical destruction through scattering or removal of the benthos are some of the harmful effects associated with bottom fishing (Jones 1992). Small, fragile invertebrate species such as polychaetes, brittle stars, and shrimp are absent or less common in areas on Georges Bank subjected to bottom fishing disturbance compared to undisturbed areas closed to fishing. Additionally, mussels and small mollusks were rare or absent from disturbed areas whereas more robust, thick-shelled bivalves, mollusks and hermit crabs were abundant at both disturbed and undisturbed areas and therefore may be resistant to the physical effects of bottom fishing. Small fish of several species were found in greater abundance in undisturbed areas suggesting that the epifauna characteristic of undisturbed areas may provide important habitat or shelter. Several other invertebrate species found in high abundance in disturbed areas included scavengers and predators (Collie et al. 1997). The aim of the present study is to better understand the impacts of the 
colonization of $D$. vexillum to the benthic community on Georges Bank, and to investigate the potential role of bottom fishing disturbance. Specifically, the study uses bottom photograph analysis and Naturalist dredge data to test the hypotheses that 1) the colonization of D. vexillum in Area 18 on Georges Bank (open to fishing) has resulted in significant changes to the benthic ecology and 2) that the changes observed in Area 19 on Georges Bank (closed to fishing) will be significantly different from those of Area 18 due to the level of bottom fishing disturbance. 


\section{METHODOLOGY}

\section{Description of Study Sites}

Samples for this study were collected from four areas of pebble/gravel habitat located on the northwestern portion of Georges Bank (Figure 1). All four areas have similar depths ranging from 40 to $65 \mathrm{~m}$, and contrasting levels of bottom fishing disturbance and Didemnum vexillum colonization (Table 1).

Areas $17 \mathrm{~W}$ and 18 are open to bottom fishing while Areas 17 and 19 have been closed to bottom fishing since 1995 with the establishment of Closed Area II. The invasive colonial tunicate, Didemnum vexillum is absent from Areas 17 and $17 \mathrm{~W}$, however it has heavily infested Areas 18 and 19.

Fieldwork and Laboratory Procedures

\section{Video and Photographic Imagery}

Video and still photography was taken on annual research cruises to Georges Bank with the USGS SEAbed Observation and Sampling System (SEABOSS). Fitted with two video cameras, a still camera, a depth sensor, and a Van Veen sediment sampler, the SEABOSS is designed to be deployed from small and large vessels to collect seabed images in coastal regions. The video equipment is powered from the vessel through a conducting cable and is housed inside a stainless steel frame. The frame is lowered over the side of the vessel with a winch and lowered to approximately $76 \mathrm{~cm}$ above the seabed. One of the two video cameras is forward facing and used by the winch operator to avoid any obstacles that may lie in the path 
of the unit. The second video camera and the 35-mm camera are downward facing and used by scientists to take continuous video and still images of the seabed at pre-set intervals or manually when something of interest is observed. To provide a scale for both the video and still images, two parallel lasers spaced $20 \mathrm{~cm}$ apart are used. Additionally, the unit has a third laser which is used to ensure that the unit is the appropriate distance from the seabed (Blackwood et al. 2000).

Still photographs of the ocean bottom were taken in Area 18 from 1994-2000 and 2003-2004, and in both Areas 18 and 19 from 2006-2007. Photographs collected from 1994-2000 were analyzed according to the methods described by Collie et al. (2000). A transparency with a $5 \mathrm{~cm}$ x $5 \mathrm{~cm}$ cell grid was overlaid onto each photo, and for each grid cell, the percent cover of hydroid, bushy bryozoan, sponge, and Filograna implexa was recorded. Free-living macrofauna as well as the dominant sediment category were also recorded for each grid cell. The data recorded for each cell were then summed across all of the cells in a photograph to give the total percent cover of colonial epifauna, frequency of free-living macrofauna, and dominant sediment type for each photograph.

Photographs collected in 2003-2004 and 2006-2007 were analyzed with a slightly different, more time-efficient method which allowed for a significantly larger number of photographs to be analyzed (Table 2). A Mathworks Matlab R2006a program was designed to record all of the same data as the grid cell method described above, in addition to the percent cover of D. vexillum. The program projects 70 random points over a bottom photograph that captures an area of the seafloor measuring $76 \mathrm{~cm} \times 51 \mathrm{~cm}$ (Figure 2). The number of points chosen was based on a 
bootstrap analysis, which determined that 70 was the smallest number of points that could accurately capture the percent cover of $D$. vexillum in a photograph. Each of the 70 points is classified by the user as one of six categories of colonial epifauna: $D$. vexillum, F. implexa, hydroid, bushy bryozoan, sponge, or other. When all 70 points have been classified, the user is then able to record the occurrence of free-living macrofauna that are present in the photograph. The last function in the program is to use a binary index to classify a primary and secondary substrate, such that the primary substrate occupies at least $50 \%$ of the area in the photograph and the secondary substrate at least $20 \%$ of the remaining area (Hixon et al. 1991). The data collected for each photograph are saved in a text file that can be used to determine the total percent cover of the six categories of colonial epifauna in each photograph analyzed.

\section{Naturalist Dredge Data}

Naturalist dredge samples were collected on annual research cruises to Georges Bank from 1994-2008 in Area 18 and from 2005-2008 in Area 19. A 1-m naturalist dredge was used to collect 1-4 replicate benthic samples in each area in each year sampled. Tows were conducted for 30-60 seconds at 1-1.5 knots to avoid overfilling and losing the sample. When the tow was completed the bag was brought to the surface and the contents emptied onto the deck for sorting. All free-living macrofauna were picked from the gravel pile and placed in containers of seawater. For large samples, gravel piles were sub-sampled. The volume of each sample was measured by shoveling gravel into 9-liter buckets. For each dredge sample, a subsample was collected by sieving one 9-liter bucket through a 5-mm screen to collect any remaining macrofauna that may have been overlooked through sorting. Each sub- 
sample was scaled up to the total sample volume afterward for data analysis. Freeliving macrofauna were removed from seawater and preserved in a 5\% buffered formalin solution and brought back to the laboratory for analysis.

In the laboratory, a lid with a mesh screen was used to drain formalin from samples and samples were rinsed under running tap water for 10 minutes to remove residual formalin. Samples were sorted by genera and placed in containers filled with tap water to delay decomposition. A dissecting microscope was used to further identify organisms to the lowest taxonomic level possible. For each taxon identified, a count and blotted weight were obtained and recorded. Data were entered in Microsoft Excel and later imported into a Microsoft Access database.

Once the data were imported into the database, the species list was filtered to remove any species that were not sampled quantitatively. These species included any organisms that were not consistently picked out of dredge piles such as colonial organisms that were attached to the substrate, and microscopic organisms (i.e. amphipods and caprellids). The resulting species list was checked for consistency among scientific names. The remaining abundance and biomass data were then standardized per liter of sediment.

Data Analysis

\section{Comparison of Photographic Analysis Methods}

Throughout the present study, two different methods were used to analyze bottoms photographs. Photographs from 1994-2000 were analyzed with a grid-cell method while photographs from 2003-2007 were analyzed with a random-point 
method, as described above. Due to the fact that these time frames also correspond to before the infestation of $D$. vexillum (1994-2001) and after the infestation of $D$. vexillum (2002-2008), it is possible that differences observed between these two time periods could be a factor of the two different photographic analysis methods used. To address this, a method comparison was performed by taking a subset of photographs analyzed with the grid-cell method and re-analyzing them with the Mathworks Matlab R2006a random-point program. Only one year of photographs collected from 1994 to 2000 were available in digital format; therefore only a subset of 16 photographs from the year 2000 could be re-analyzed with the random point program.

Of the five categories of colonial epifauna, only D. vexillum, F. implexa and hydroid were present in more than one photograph of the subset and used in this analysis. A series of two-tailed t-tests used the percent cover of each colonial epifauna taxon calculated in the grid cell method and that calculated with the random-point program, to look for significant differences between the two photographic analysis methods.

\section{Spatial Autocorrelation Analysis}

Spatial data such as data taken along a photographic transect typically exhibit spatial autocorrelation, such that data collected at points close together spatially are not independent of each other. One of the assumptions of parametric statistics however, is that observations are independent of each other, an assumption that is often violated with spatial data. As a result, it is important to test for and subsequently address spatial autocorrelation in data prior to data analysis. 
For the present study, a spatial autocorrelation analysis was performed on photographic data to investigate whether photographs taken at locations close together are independent of each other. Due to the fact that spatial autocorrelation depends heavily on location and the distance between observations, photographic data from the year 2003, for which Global Positioning System (GPS) coordinates were readily available, were chosen for this analysis. Photographic data from 2003 used for this analysis included GPS coordinates and the arcsine square root transformed percent cover of D. vexillum collected from three transects comprising a total of 60 bottom photographs. Only the variable $D$. vexillum was used for this analysis because it was the only category of colonial epifauna observed in nearly all of the photographs analyzed in 2003. Data were imported into SAS and used to calculate Moran's I and Geary's c, two test statistics that determine if autocorrelation exists.

Once I verified that autocorrelation existed among photographs, it was then important to calculate the distance at which no autocorrelation existed, as this determined whether photographs could be used as individual observations or if they should be averaged across transects. To determine the distance at which no autocorrelation exists, a larger dataset containing photographic data collected from 2003 and 2004 was used to calculate a variogram in R. A variogram plots the variance that exists between photographs against the distance between photographs. The variance increases as the distance increases until it reaches an asymptote or point of no autocorrelation. Data used for this analysis included GPS coordinates and the arcsine square root transformed percent cover of $D$. vexillum collected from 26 transects comprising a total of 514 bottom photographs. 


\section{Impact of D. vexillum on the Benthic Community}

To determine if a significant relationship exists between the percent cover of D. vexillum and dominant sediment type on Georges Bank, a one-way ANOVA was used. To investigate the long-term effects of D. vexillum in Area 18 on the four other categories of colonial epifauna identified in bottom photographic analysis, a series of nested ANOVA's were used to look for significant differences in the percent cover of each colonial epifauna taxon before the colonization of D. vexillum in 2002 compared to after. To understand the effect of $D$. vexillum on the frequency of free-living macrofauna identified in bottom photographs, a GLM with Poisson link function was used.

To examine the long-term impact of $D$. vexillum on the benthic species composition in Area 18, the PRIMER 6 software package was used. The standardized Naturalist dredge abundance data of species known to be sampled quantitatively were square-root transformed and used to create a Bray Curtis similarity matrix. The Bray Curtis similarity matrix was then used to calculate a non-metric Multi-Dimensional Scaling (MDS) plot to ordinate naturalist dredge samples and look for differences in species composition. An analysis of similarity (ANOSIM) test was used to test the significance of any differences, and a similarity of percentages (SIMPER) analysis was used to determine which species were responsible for the change. A two-way ANOVA was used to test whether the abundance of organisms identified in the SIMPER analysis differed significantly in areas with $D$. vexillum present compared to areas with no $D$. vexillum. The two factors in the two-way ANOVA were $D$. vexillum 
and year. A significant $D$. vexillum $\mathrm{x}$ year interaction indicates that the $D$. vexillum infestation significantly affected the abundance of the particular species.

\section{Impact of Bottom Fishing Disturbance on D. vexillum}

To investigate the effects of bottom fishing disturbance and the colonization of D. vexillum, a series of analyses were conducted comparing Area 18, open to fishing, to Area 19, closed to fishing. A two-way ANOVA was used to test for significant differences in the percent cover of each colonial epifaunal taxon identified in bottom photographs between Area 18 and Area 19 with both year and area as factors. To look for significant differences in the frequency of free-living macrofauna in Area 18 compared to Area 19, a GLM with a Poisson link function was used. To look for relationships between the percent cover of colonial epifauna and the frequency of freeliving macrofauna, square-root transformed frequency data were aggregated over transects and used to calculate a Bray-Curtis similarity matrix using the PRIMER 6 software package. From this matrix, an MDS plot was used to ordinate the photographic transects and look for differences between Areas 18 and 19. The routine BIOENV was used to calculate the rank correlation between the similarity matrix of aggregated frequency data and the percent cover of colonial epifauna, averaged over transects.

To investigate the effects of bottom fishing disturbance and the infestation of D. vexillum on benthic species composition, the PRIMER 6 software package was used. The standardized Naturalist dredge abundance data of species known to be sampled quantitatively were square-root transformed and used to create a Bray Curtis similarity matrix. The Bray Curtis similarity matrix was then used to calculate an 
MDS plot, and conduct a two-way ANOSIM test and a SIMPER analysis. A two-way ANOVA was used to test whether the abundance of organisms identified in the SIMPER analysis differed significantly in an area with bottom fishing disturbance compared to an area with no bottom fishing disturbance. The two factors in the twoway ANOVA were area and year. Year was included to determine if there was a significant year effect within each area. 


\section{RESULTS}

\section{Comparison of Photographic Analysis Methods}

Two different photographic analysis methods used in a method comparison identified three out of five possible categories of colonial epifauna taxa: D. vexillum, F. implexa, and hydroid. While the grid cell method consistently identified the presence of colonial epifauna in a larger number of photographs than the random-point program (Table 3), a series of two-tailed t-tests indicated no significant difference in percent cover between the two photographic analysis methods (Table 4).

\section{Spatial Autocorrelation Analysis}

The spatial autocorrelation analysis revealed that a significant spatial autocorrelation exists among photographs (Table 5). Both test statistics used, Moran's I and Geary's c, were statistically significant. A variogram in R calculated the distance at which no autocorrelation exists to be $0.7 \mathrm{~km}$, nearly equal to the maximum transect length of $0.8 \mathrm{~km}$ (Figure 3). As a result, photographs were averaged across transects prior to data analysis to fulfill the assumption of independent observations.

\section{Impact of D. vexillum on the Benthic Community}

The results of a one-way ANOVA revealed no significant relationship between the percent cover of $D$. vexillum and dominant sediment type in Area $18(\mathrm{p}=0.141)$. While this suggests that dominant sediment type does not play a role in the ability of D. vexillum to colonize an area, it should be noted that the majority of the photographs used in this analysis had pebble as the dominant sediment type so this result could be due to the limited amount of photographs with a substrate other than pebble. 
As expected, a nested ANOVA used to investigate the long-term effects of $D$. vexillum in Area 18 revealed the percent cover of $D$. vexillum was significantly greater after the infestation versus before the infestation $(\mathrm{p}<0.001)$ (Figure 4). In the case of F. implexa, there was a significant decrease after the infestation versus before the infestation $(\mathrm{p}<0.001)$, however there was also a significant year effect $(\mathrm{p}=0.026)$. Looking more closely at the percent cover of $F$. implexa over time, there appeared to be downward trend in percent over the time series before the invasion of $D$. vexillum (1994-2000), indicating that something other than D. vexillum was responsible for this decrease over time. No significant difference in percent cover was found for hydroid, bushy bryozoa or sponge when looking at before versus after the infestation of $D$. vexillum.

In looking for relationships between the percent cover of colonial epifauna and the frequency of free-living macrofauna, a significant negative relationship was found to exist between the frequency of free-living macrofauna and the percent cover of $D$. vexillum $(\mathrm{p}=0.004)$; as the percent cover of D. vexillum increased, the frequency of macrofauna decreased (Figure 5). Conversely, F. implexa, hydroid, and sponge were all found to have significant positive relationships with the frequency of free-living macrofauna (Figures 6-8, Table 6). There was no significant relationship between bushy bryozoa and free-living macrofauna.

An MDS plot based on the abundance of 97 species used to investigate the long-term impact of D. vexillum on the benthic species composition in Area 18 showed distinct differences in species composition in Area 18 before the infestation (1994-2001) of D. vexillum versus after the infestation (2002-2008) (Figure 9). An 
ANOSIM based on abundance data indicated a significant difference between the before and after samples for Area $18(\mathrm{R}=0.329, \mathrm{p}=0.001)$. A SIMPER test identified two polychaete species, Harmothoe extenuata and Nereis zonata as the two species largely responsible for the difference in species composition. Nested ANOVA's confirmed a significant difference in both polychaete species in Area 18 before the infestation compared to after the infestation (Table 7). A two-way ANOVA revealed a significant time (before/after) x treatment (present/absent) interaction indicating that the abundance of these two polychaetes increased significantly post invasion in Areas 18 and 19 compared to two reference areas without D. vexillum, Areas 17 and 17W (Table 8, Figure 10).

Impact of Bottom Fishing Disturbance on D. vexillum

A series of two-way ANOVA's to look at the effect of bottom fishing disturbance and the colonization of $D$. vexillum, revealed significant differences in the percent cover of $D$. vexillum, $F$. implexa, hydroid, and bushy bryozoa between Area 18 and Area 19 in 2006 and 2007 (Table 9). A significant year effect was also seen for D. vexillum. No significant difference between Area 18 and Area 19 was found for the percent cover of sponge. Hydroid and bushy bryozoan had a higher percent cover in Area 18 , while D. vexillum and $F$. implexa both had a higher percent cover in Area 19 (Figure 11). D. vexillum also had a higher percent cover in 2006 compared to 2007 for both Area 18 and Area 19.

A GLM with a Poisson link function revealed a significant difference in the frequency of free-living macrofauna in Area 18 versus Area $19(\mathrm{p}=0.0342)$. In both 
2006 and 2007, there was a significantly higher frequency of macrofauna in Area 18 compared to Area 19.

A series of MDS plots used to ordinate photographic transects also revealed a difference in macrofauna between Area 18 and 19 in 2006 and 2007 (Figures 12-15). A greater percent cover of D. vexillum and F. implexa was found in Area 19. In contrast, a greater percent cover of hydroid and bushy bryozoa was observed in Area 18. An analysis of the macrofaunal data with the routine BIOENV indicated that the similarity matrix used to ordinate the transects was significantly correlated to the percent cover of colonial epifauna with D. vexillum, F. implexa, and hydroid contributing most to the ordination $(\rho=0.234, p=0.01)$. In general transects that grouped together with a higher percent cover of colonial epifauna, corresponded to transects with a higher abundance of anemones suggesting a strong association between anemones and colonial epifauna.

An MDS plot calculated to investigate the effects of bottom fishing disturbance and $D$. vexillum on the benthic community, based on the abundance of 91 species, showed a distinct difference in species composition in Area 18 (open to fishing) versus Area 19 (closed to fishing) following the invasion of D. vexillum (2005-2008) (Figure 9, Figure 16). A two-way ANOSIM analysis on the abundance data indicated a significant difference between Area 18 and Area 19 after the infestation (Global R = $0.789, \mathrm{p}=0.001)$ as well as significant difference between years (Global $\mathrm{R}=0.786, \mathrm{p}$ $=0.001)$. A SIMPER test identified the polychaete $N$. zonata and the anemone Urticina felina as being responsible for this change in species composition. Two-way ANOVA's indicated significant differences in N. zonata and U. felina in Area 18 
compared to Area 19 for 2005-2008 (Table 10). Urticina felina was found to have a significantly higher abundance in Area 18 while $N$. zonata had a significantly higher abundance in Area 19. 


\section{DISCUSSION}

Impact of D. vexillum on the Benthic Community

The invasive tunicate $D$. vexillum was first documented to have colonized areas of pebble/gravel habitat on Georges Bank in 2002. In 2005, just three years after the species was first noted, it was estimated that the tunicate had spread dramatically and encompassed an area of $\sim 230 \mathrm{~km}^{2}$ in two areas on Georges Bank (Valentine et al. 2007b). The results presented here demonstrate that the tunicate remains well established in Area 18, despite a decrease in percent cover over time, and has had a significant impact on the benthic community.

Detailed analysis of bottom photographs in Area 18 revealed a significant decrease in the percent cover of the calcareous tubeworm $F$. implexa following the invasion of $D$. vexillum in 2002 , but also revealed a significant year effect over the time series. No significant before/after differences were found for hydroids, bushy bryozoans or sponges. While examining bottom photographs it was evident that certain colonial epifauna taxa, such as hydroid and bushy bryozoans that have erect structures, may not be as susceptible to the impacts of $D$. vexillum as result of the tunicate colonizing around the base of the hydroid or bushy bryozoa stem and not completely smothering the colony. Filograna implexa colonies in Area 18 on Georges Bank however, appeared to be on a decreasing trend in Area 18 well before the infestation of $D$. vexillum (Figure 4). With the closure of Area II in 1995, it is likely that fishing effort increased in Area 18 as vessels were displaced from the closed area (Collie et al. 2005, Asch et al. 2008). Due to the fragile and structurally complex structure of $F$. implexa, an increase in fishing effort in Area 18 could have been 
responsible for the decline in F. implexa from 1994-2000 rather than the colonization of D. vexillum. This is further supported by the work of Collie et al. (2000) who compared areas with contrasting levels of bottom fishing disturbance on Georges Bank and found that $F$. implexa had a higher percent cover in undisturbed areas, suggesting that bottom fishing disturbance was limiting the abundance of this polychaete species.

A significant negative relationship was found between the overall abundance of free-living macrofauna and D. vexillum, where, as percent cover increased, freeliving macrofauna decreased. Conversely, F. implexa had a significant positive relationship with the frequency of free-living macrofauna. These results indicate that D. vexillum will not only have a direct negative impact on macrofauna, but will also indirectly impact macrofauna due to the negative effect $D$. vexillum was shown to have on F. implexa above. It has been suggested that the heterogeneous substrate and polychaete tubes characteristic of the bottom in some areas on Georges Bank, provides suitable habitat and refuge to free-living macrofauna (Thouzeau et al. 1991, Collie et al. 1997). Therefore, the ability of D. vexillum to homogenize the substrate and reduce heterogeneity may be deterring free-living macrofauna from living in close association to the tunicate mats present in Area 18.

In contrast, two polychaete species, Nereis zonata and Harmothoe extenuata, appear to be living in close association with D. vexillum mats in Area 18. Analysis of Naturalist dredge data indicated a significant increase in the abundance of these two polychaetes following the invasion of $D$. vexillum, which resulted in a significant change in benthic species composition. Previous research has suggested that the tunicate mat may offer these polychaetes protection from bottom feeders (Lengyel et 
al. 2009), which have been shown through stomach-content analysis to depend on the benthos for a large proportion of their diet (Smith et al. 2013).

\section{Impact of Bottom Fishing Disturbance on D. vexillum}

Similar to the pattern observed in Area 18, a decline in the percent cover of $D$. vexillum over time was also observed in Area 19, from 44\% in 2006 to $18 \%$ in 2007. Analysis of bottom photographs taken in two areas of pebble/gravel habitat on Georges Bank revealed a significantly higher percent cover in Area 19 (closed to fishing) compared to Area 18 (open to fishing). The level of bottom fishing disturbance in Area 18 may be directly facilitating the spread of $D$. vexillum through physical disturbance and fragmentation of colonies. Patchy distributions of $D$. vexillum colonies were frequently observed in bottom photographs suggesting that after fragments are dislodged from the substrate following fishing activity, the colony is able to survive and subsequently re-attach to the substrate. In Area 19 bottom fishing may be indirectly facilitating the spread of $D$. vexillum. Lengyel et al. (2009) suggested that due to $D$. vexillum encrusting the shells of bivalves such as sea scallops, that fishing vessels harvesting scallops in Area 18, but subsequently discarding the shells in Area 19 following on-board processing, could aid in the spread of D. vexillum in Area 19.

In addition to the observed impacts on $D$. vexillum, bottom fishing disturbance was also seen to play a significant role in the percent cover of $F$. implexa, where percent cover was significantly higher in Area 19 when compared to Area 18. Although D. vexillum may be limiting the percent cover of F. implexa in Area 18, further analysis suggests that bottom fishing disturbance in Area 18 may also be 
playing a significant role. The complex physical structure of $F$. implexa, specifically the calcareous tube it builds, may be highly susceptible to damage from bottom fishing disturbance and could explain the higher percent cover seen in Area 19, closed to fishing.

The higher abundance of free-living macrofauna observed in Area 18 compared to Area 19 again supports the notion that D. vexillum colonization may lead to emigration of macrofauna to more favorable heterogeneous habitat on Georges Bank given the higher percent cover of D. vexillum in Area 19. Additionally, this suggests that bottom fishing disturbance in Area 18 is not negatively impacting the frequency of free-living macrofauna. Analysis of naturalist dredge samples further confirmed that there was a significant difference in species composition in Area 18 compared to Area 19, and the two species that were identified for being largely responsible for this change were $N$. zonata and $U$. felina. As expected, $N$. zonata had a higher percent cover in Area 19 most likely due to the higher percent cover of $D$. vexillum in Area 19 and the positive impact of the tunicate mat on this polychaete. Bottom fishing disturbance could also be somewhat limiting the abundance in Area 18 when compared to Area 19. Urticina felina however, was more abundant in Area 18 which conflicts with the findings of Collie et al. (2000) that anemones were found to be more abundant in undisturbed areas and thus heavily impacted by bottom fishing disturbance. It has also been observed in bottom photographic analysis that anemones seem to be resistant to overgrowth by $D$. vexillum colonies suggesting that the tunicate is not limiting the abundance of this species. Due to the fact that U. felina is typically found attached to the substrate, it is plausible that anemones were not consistently 
picked from the substrate during the sorting process and thus the difference seen in Area 18 versus Area 19 is the result of sampling error.

Several caveats should be taken into account when considering the results of this study. While analysis of bottom photographs to quantify colonial epifauna and free-living macrofauna is an acceptable approach and technique, due to the twodimensional nature of the photographs as well as the ability of organisms to cover each other or burrow into the substrate, this method could be missing or underestimating abundance. While the conclusions based on photographic data from Area 18 were based on a long time-series of data (1994-2007), the earlier part of the time series had a very limited number of photographs that were analyzed compared to later years due to the time-consuming photographic analysis method employed. Additionally, data used for comparisons between Areas 18 and 19 was a relatively short time series, comprising only two years of photographic data and four years of Naturalist dredge data. Naturalist dredge data contained only species known to be sampled quantitatively, however it is possible that $U$. felina was not consistently picked from the substrate during the sorting process. Finally, due to the contrasting levels of bottom fishing disturbance as well as percent cover of $D$. vexillum, it was difficult to discern what played a more significant role in the observed changes between the two areas.

\section{Conclusion}

This research demonstrates that $D$. vexillum is a resilient, highly competitive, invasive species that is capable of surviving and colonizing the depths of Georges Bank despite frequent disturbance from bottom fishing. While the direct community 
level impacts $D$. vexillum has had on Georges Bank are significant, there are potential indirect impacts that could result from the invasion. Smith et al. (2013) demonstrated that the diet of commercially important species of finfish, including winter flounder and haddock, depends heavily on the benthic community on Georges Bank. This suggests that $D$. vexillum could have indirect impacts at higher trophic levels by affecting prey availability. There is also large concern that the ability of D. vexillum to transform heterogeneous pebble/gravel habitat into a homogenous tunicate mat, may negatively affect the settlement of sea scallop larvae, which have been shown to favor more structurally complex habitat (Hart and Chute 2004).

Analysis of bottom photographic data and Naturalist dredge data from two areas of pebble/gravel habitat on Georges Bank revealed significant impacts to the benthic environment as a result of the colonization of $D$. vexillum and bottom fishing disturbance. These results not only confirm findings from our previous research (Lengyel et al. 2009), but build upon and expand those findings with additional years of research. Moreover, by using more recent years of data and drawing the same conclusions, we were able to confirm that the previously observed changes in benthic community composition were not short-term effects from the stress of the invasion, but rather long-term trends representing a shift from one community structure to another. 


\section{LIST OF REFERENCES}

Asch RG, Collie JS (2008) Changes in a benthic megafaunal community due to disturbance from bottom fishing and the establishment of a fishery closure. Fishery Bulletin 106(4): 438-456

Backus RH (1987) Geology. In: Backus RH, Bourne DW (eds) Georges Bank, MIT Press, Massachusetts, USA, pp 22-24

Bax N, Williamson A, Aguero M, Gonzalez E, Geeves W (2003) Marine invasive alien species: a threat to global biodiversity. Marine Policy 27: 313-323

Blackwood D, Parolski K, Valentine P (2000) Seabed Observation and Sampling System: U.S. Geological Survey Fact Sheet FS-142-00

Bullard SG, Sedlack B, Reinhardt JF, Littly C, Gareau K, Whitlatch RB (2007) Fragmentation of colonial ascidians: differences in reattachment capability among species. Journal of Experimental Marine Biology and Ecology 342: 166-168

Collie JS, Escanero GA, Valentine PC (1997) Effects of bottom fishing on the benthic megafauna of Georges Bank. Marine Ecology Progress Series 155: 159-172

Collie JS, Escanero GA, Valentine PC (2000) Photographic evaluation of the impacts of bottom fishing on benthic epifauna. ICES Journal of Marine Science 57: 9871001

Collie JS, Hermsen J, Valentine P, Almeida F (2005) Effects of fishing on gravel habitats: assessment and recovery of benthic megafauna on Georges Bank. American Fisheries Society Symposium 41: 325-343

German AW (1987) History of the early fisheries, 1720-1930. In: Backus RH, Bourne DW (eds) Georges Bank, MIT Press, Massachusetts, USA, pp 409-424

Hart DR, Chute AS (2004) Essential fish habitat source document. Sea scallop, Placopecten magellanicus, life history and habitat characteristics. DIANE Publishing

Hennemuth RC, Rockwell S (1987) History of fisheries management and conservation. In: Backus RH, Bourne DW (eds) Georges Bank, MIT Press, Massachusetts, USA, pp 430-446

Hixon MA, Tissot BN, Pearcy WG (1991) Fish assemblages of rocky banks of the Pacific Northwest: Final Report (No. 52). US Dept. of the Interior, Minerals Management Service, Pacific OCS Region 
Jones JB (1992) Environmental impact of trawling on the seabed: a review. New Zealand Journal of Marine and Freshwater Research 26(1): 59-67

Kott, P (2002) A complex didemnid ascidian from Whangamata, New Zealand. Journal of the Marine Biological Association of the UK 82(4): 625-628

Lengyel NL, Collie JS, Valentine, PC (2009) The invasive colonial ascidian Didemnum vexillum on Georges Bank-Ecological effects and genetic identification. Aquatic Invasions 4(1): 143-152

Lodge DM, Williams S, MacIsaac HJ, Hayes KR, Leung B, Reichard S, Mack RN, Moyle PB, Smith M, Andow DA, Carlton JT, McMichael A (2006) Biological invasions: recommendations for US policy and management. Ecological Applications 16(6): 2035-2054

Mercer JM, Whitlatch RB, Osman RW (2009) Potential effects of the invasive colonial ascidian (Didemnum vexillum Kott, 2002) on pebble-cobble bottom habitats in Long Island Sound, USA. Aquatic Invasions 4(1): 133-142

Morris JA Jr, Carman MR, Hoagland KE, Green-Beach ER, Karney RC (2009) Impact of the invasive colonial tunicate Didemnum vexillum on the recruitment of the bay scallop (Argopecten irradians irradians) and implications for recruitment of the sea scallop (Placopecten magellanicus) on Georges Bank. Aquatic Invasions 4(1): 207-211

Murawski SA, Brown R, Lai HL, Rago PJ, Hendrickson L (2000) Large-scale closed areas as a fishery-management tool in temperate marine systems: the Georges Bank experience. Bulletin of Marine Science 66(3): 775-798

Smith BE, Collie JS, Lengyel NL (2013) Effects of chronic bottom fishing on the benthic epifauna and diets of demersal fishes on northern Georges Bank. Marine Ecology Progress Series 472: 199-217

Stefaniak L, Lambert G, Gittenberger A, Zhang H, Lin S, Whitlatch RB (2009) Genetic conspecificity of the worldwide populations of Didemnum vexillum Kott, 2002. Aquatic Invasions 4(1): 29-44

Stefaniak L, Zhang H, Gittenberger A, Smith K, Holsinger K, Lin S, Whitlatch RB (2012) Determining the native region of the putatively invasive ascidian Didemnum vexillum Kott, 2002. Journal of Experimental Marine Biology and Ecology 422: 64-71

Thouzeau G, Robert G, Smith SJ (1991) Spatial variability in distribution and growth of juvenile and adult sea scallops Placopecten magellanicus (Gmelin) on eastern Georges Bank (Northwest Atlantic). Marine Ecology Progress Series 74: 205-218 
Uchupi E, Austin JA Jr (1987) Morphology. In: Backus RH, Bourne DW (eds) Georges Bank, MIT Press, Massachusetts, USA, pp 25-30

Valentine PC, Carman MR, Blackwood DS, Heffron EJ (2007a) Ecological observations on the colonial ascidian Didemnum sp. in a New England tide pool habitat. Journal of Experimental Marine Biology and Ecology 342(1): 109-121

Valentine PC, Collie JS, Reid RN, Asch RG, Guida VG, Blackwood DS (2007b) The occurrence of the colonial ascidian Didemnum sp. on Georges Bank gravel habitat - Ecological observations and potential effects on groundfish and scallop fisheries. Journal of Experimental Marine Biology and Ecology 342(1): 179-181

Valentine PC, Carman MR, Dijkstra J, Blackwood DS (2009) Larval recruitment of the invasive colonial ascidian Didemnum vexillum, seasonal water temperatures in New England coastal and offshore waters, and implications for spread of the species. Aquatic Invasions 4(1) 153-168 
Table 1. Description of study sites on northern Georges Bank.

\begin{tabular}{lllll}
\hline Study Site & 18 & 19 & 17 & $17 \mathrm{~W}$ \\
\hline Latitude (N) & $41^{\circ} 57.2^{\prime}$ & $41^{\circ} 55.78^{\prime}$ & $42^{\circ} 04.6^{\prime}$ & $42^{\circ} 04.9^{\prime}$ \\
Longitude (W) & $67^{\circ} 31.0^{\prime}$ & $67^{\circ} 17.94^{\prime}$ & $67^{\circ} 15.6^{\prime}$ & $67^{\circ} 21.3^{\prime}$ \\
Depth Range (m) & $41-65$ & $52-55$ & $44-49$ & $50-51$ \\
D. vexillum & Present & Present & Absent & Absent \\
Fishery Status & Open & Closed & Closed & Open \\
\hline
\end{tabular}


Table 2. Number of photographs analyzed in Areas 18 and 19.

\begin{tabular}{ccc}
\hline Year & Area 18 & Area 19 \\
\hline 1994 & 12 & - \\
1996 & 16 & - \\
1997 & 13 & - \\
1998 & 15 & - \\
1999 & 14 & - \\
2000 & 16 & - \\
2003 & 60 & - \\
2004 & 456 & - \\
2006 & 313 & 514 \\
2007 & 264 & 198 \\
\hline
\end{tabular}


Table 3. Number of photographs that each colonial epifauna taxon is identified in for each photographic analysis method.

\begin{tabular}{ccc}
\hline Colonial Epifauna Taxon & $\begin{array}{c}\text { Grid Cell } \\
\text { Method }\end{array}$ & Random-Point Method \\
\hline D. vexillum & 2 & 1 \\
F. implexa & 12 & 2 \\
Hydroid & 7 & 2 \\
\hline
\end{tabular}


Table 4. Percent cover of colonial epifauna estimated with grid-cell method by RA and the random-point program by NL. The initials RA and NL refer to the analyst who used each of the methods. The mean percent cover of each taxon was compared with a two-tailed t-test.

\begin{tabular}{lcccccc}
\hline & \multicolumn{2}{c}{ Didemnum vexillum } & \multicolumn{2}{c}{ Filograna implexa } & \multicolumn{2}{c}{ Hydroid } \\
\cline { 2 - 7 } & RA & NL & RA & NL & RA & NL \\
\hline Mean & 0.33 & 2.38 & 0.42 & 0.24 & 0.52 & 1.22 \\
Variance & 0.12 & 17.01 & 0.09 & 0.31 & 0.34 & 5.05 \\
Coefficient of Variation & 1.05 & 1.73 & 0.73 & 2.34 & 1.12 & 1.84 \\
Observations & 3.00 & 3.00 & 12.00 & 12.00 & 7.00 & 7.00 \\
Pooled Variance & 8.57 & & 0.20 & & 2.70 & \\
Degrees of freedom & 4.00 & & 22.00 & & 12.00 & \\
t Statistic & -0.86 & & 1.01 & & -0.80 & \\
P(T<=t) two-tail & 0.44 & & 0.33 & & 0.44 & \\
t Critical two-tail & 2.78 & & 2.07 & & 2.18 & \\
\hline
\end{tabular}


Table 5. Test statistics from autocorrelation analysis. Moran's I and Geary's c are both used to test for spatial autocorrelation. A $\mathrm{Pr}>|\mathrm{Z}|$ less than 0.05 indicated that spatial autocorrelation exists.

\begin{tabular}{cccccc}
\hline \multicolumn{7}{c}{ Autocorrelation Statistics } \\
\hline Coefficient & Observed & Expected & Std Dev & $\mathrm{Z}$ & $\operatorname{Pr}>|\mathrm{Z}|$ \\
Moran's I & 0.141 & -0.0169 & 0.0429 & 3.68 & 0.0002 \\
Geary's c & 0.708 & 1 & 0.0909 & -3.22 & 0.0013 \\
\hline
\end{tabular}


Table 6. GLM output showing the relationship between the percent cover of colonial epifauna and free-living macrofauna.

\begin{tabular}{lllll}
\hline Model & Estimate & Standard error & $\mathrm{Z}$ & $\operatorname{Pr}(>\mathrm{Z})$ \\
\hline Intercept & 1.2668 & 0.1297 & 9.768 & $<0.001$ \\
Didemnum vexillum & -0.0135 & 0.0045 & 0.005 & 0.0038 \\
& & & & \\
Intercept & 1.3407 & 0.0618 & 21.699 & $<0.001$ \\
Filograna implexa & 0.0391 & 0.0090 & 4.335 & $<0.001$ \\
& & & & \\
Intercept & 1.0736 & 0.0947 & 11.336 & $<0.001$ \\
Hydroid & 0.1097 & 0.0399 & 2.751 & 0.0059 \\
& & & & \\
Intercept & 1.2580 & 0.0642 & 19.6 & $<0.001$ \\
Sponge & 0.0220 & 0.0026 & 8.62 & $<0.001$ \\
\hline
\end{tabular}


Table 7. Nested ANOVA output showing the significant difference of two polychaete species in Area 18 before (1994-2001) and after (2002-2008) the invasion of $D$. vexillum. Degrees of freedom for the F statistic were 1 and 10 for Harmothoe extenuata, and 1 and 12 for Nereis zonata.

\begin{tabular}{|c|c|c|c|c|c|}
\hline Species & Model & $\begin{array}{l}\text { Sum of } \\
\text { Squares }\end{array}$ & $\begin{array}{l}\text { Mean } \\
\text { Sum of } \\
\text { Squares }\end{array}$ & $\mathrm{F}$ & $\operatorname{Pr}(>\mathrm{F})$ \\
\hline \multirow[t]{3}{*}{ Harmothoe extenuata } & Invasion & 1.0087 & 1.0087 & 50.032 & $<0.001$ \\
\hline & Invasion:Year & 0.9661 & 0.0966 & 4.792 & 0.001 \\
\hline & Residuals & 0.4234 & 0.0202 & & \\
\hline \multirow[t]{3}{*}{ Nereis zonata } & Invasion & 2.002 & 2.0023 & 23.871 & $<0.001$ \\
\hline & Invasion:Year & 6.592 & 0.5493 & 6.549 & $<0.001$ \\
\hline & Residuals & 2.852 & 0.0839 & & \\
\hline
\end{tabular}


Table 8. Two-way ANOVA output showing the significant increase in abundance of two polychaete species after the infestation of $D$. vexillum in two areas with $D$. vexillum present compared to reference areas without $D$. vexillum. The degrees of freedom for all $\mathrm{F}$ statistics are 1. Invasion represents before the infestation of $D$. vexillum (1994-2001) and after the infestation (2002-2008). Infestation represents whether $D$. vexillum is present or not in an area.

\begin{tabular}{|c|c|c|c|c|c|}
\hline Species & Model & $\begin{array}{l}\text { Sum of } \\
\text { Squares }\end{array}$ & $\begin{array}{l}\text { Mean } \\
\text { Sum of } \\
\text { Squares }\end{array}$ & $\mathrm{F}$ & $\operatorname{Pr}(>\mathrm{F})$ \\
\hline \multirow[t]{4}{*}{ Harmothoe extenuata } & Invasion & 0.010 & 0.010 & 0.244 & 0.623 \\
\hline & Infestation & 0.171 & 0.171 & 4.107 & 0.046 \\
\hline & Invasion:Infestation & 2.169 & 2.169 & 51.974 & $<0.001$ \\
\hline & Residuals & 3.631 & 0.042 & & \\
\hline \multirow[t]{4}{*}{ Nereis zonata } & Invasion & 0.550 & 0.550 & 2.051 & 0.155 \\
\hline & Infestation & 5.900 & 5.902 & 22.006 & $<0.001$ \\
\hline & Invasion:Infestation & 6.200 & 6.199 & 23.112 & $<0.001$ \\
\hline & Residuals & 32.720 & 0.268 & & \\
\hline
\end{tabular}


Table 9. Two-way ANOVA output revealing the differences in percent cover of colonial epifauna between Areas 18 and 19. The degrees of freedom for the F statistic for Area and Year were both 1.

\begin{tabular}{|c|c|c|c|c|c|}
\hline Species & Model & $\begin{array}{l}\text { Sum of } \\
\text { Squares }\end{array}$ & $\begin{array}{l}\text { Mean } \\
\text { Sum of } \\
\text { Squares }\end{array}$ & $\mathrm{F}$ & $\operatorname{Pr}(>\mathrm{F})$ \\
\hline \multirow{4}{*}{ Didemnum vexillum } & Area & 41.400 & 41.380 & 6.149 & 0.015308 \\
\hline & Year & 92.700 & 92.720 & 13.779 & 0.000384 \\
\hline & Area:Year & 9.800 & 9.790 & 1.454 & 0.231507 \\
\hline & Residuals & 524.900 & 6.730 & & \\
\hline \multirow[t]{4}{*}{ Filograna implexa } & Area & 0.574 & 0.574 & 17.116 & $8.8 \mathrm{E}-05$ \\
\hline & Year & 0.052 & 0.052 & 1.554 & 0.216 \\
\hline & Area:Year & 0.022 & 0.022 & 0.649 & 0.423 \\
\hline & Residuals & 2.615 & 0.034 & & \\
\hline \multirow[t]{4}{*}{ Hydroid } & Area & 3.231 & 3.231 & 9.315 & 0.00311 \\
\hline & Year & 0.393 & 0.393 & 1.134 & 0.29024 \\
\hline & Area:Year & 1.480 & 1.480 & 4.267 & 0.04218 \\
\hline & Residuals & 27.055 & 0.347 & & \\
\hline \multirow[t]{4}{*}{ Bryozoa } & Area & 2.652 & 2.652 & 7.786 & 0.00662 \\
\hline & Year & 0.090 & 0.090 & 0.264 & 0.60855 \\
\hline & Area:Year & 0.113 & 0.113 & 0.331 & 0.56668 \\
\hline & Residuals & 26.567 & 0.341 & & \\
\hline \multirow[t]{4}{*}{ Sponge } & Area & 0.002 & 0.002 & 0.015 & 0.902 \\
\hline & Year & 0.153 & 0.153 & 0.986 & 0.324 \\
\hline & Area:Year & 0.123 & 0.123 & 0.796 & 0.375 \\
\hline & Residuals & 12.091 & 0.156 & & \\
\hline
\end{tabular}


Table 10. Two-way ANOVA output showing the significant increase in abundance of two species after the infestation of D. vexillum in Area 18 versus Area 19.

\begin{tabular}{lllllll}
\hline & & \multicolumn{5}{c}{ Mean } \\
Species & Model & df & $\begin{array}{l}\text { Sum of } \\
\text { Squares }\end{array}$ & $\begin{array}{l}\text { Sum of } \\
\text { Squares }\end{array}$ & F & Pr(>F) \\
\hline Nereis zonata & Area & 1 & 2.905 & 2.905 & 14.210 & 0.001 \\
& Area:Year & 3 & 7.753 & 2.584 & 12.640 & $<0.001$ \\
& Residuals & 22 & 4.498 & 0.205 & & \\
& & & & & & \\
\multirow{5}{*}{ Urticina felina } & Area & 1 & 0.840 & 0.840 & 16.137 & 0.002 \\
& Area:Year & 3 & 0.333 & 0.111 & 2.134 & 0.159 \\
& Residuals & 10 & 0.520 & 0.052 & & \\
\hline
\end{tabular}




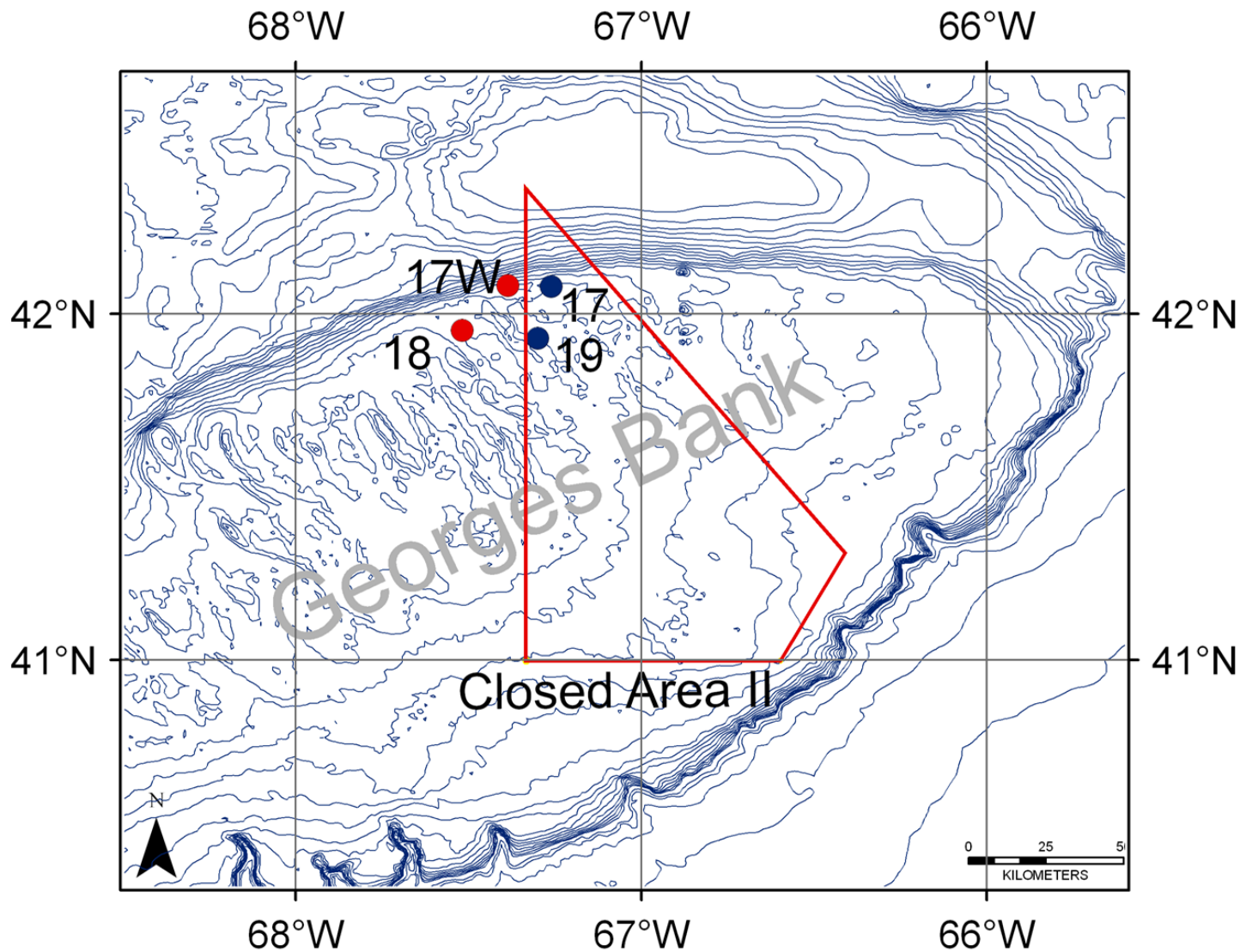

Figure 1. Study sites on Georges Bank. Areas 18 and $17 \mathrm{~W}$ are open to fishing and Areas 19 and 17 are closed to fishing. D. vexillum is present in both Area 18 and Area 19 and absent from Areas 17 and 17W. 


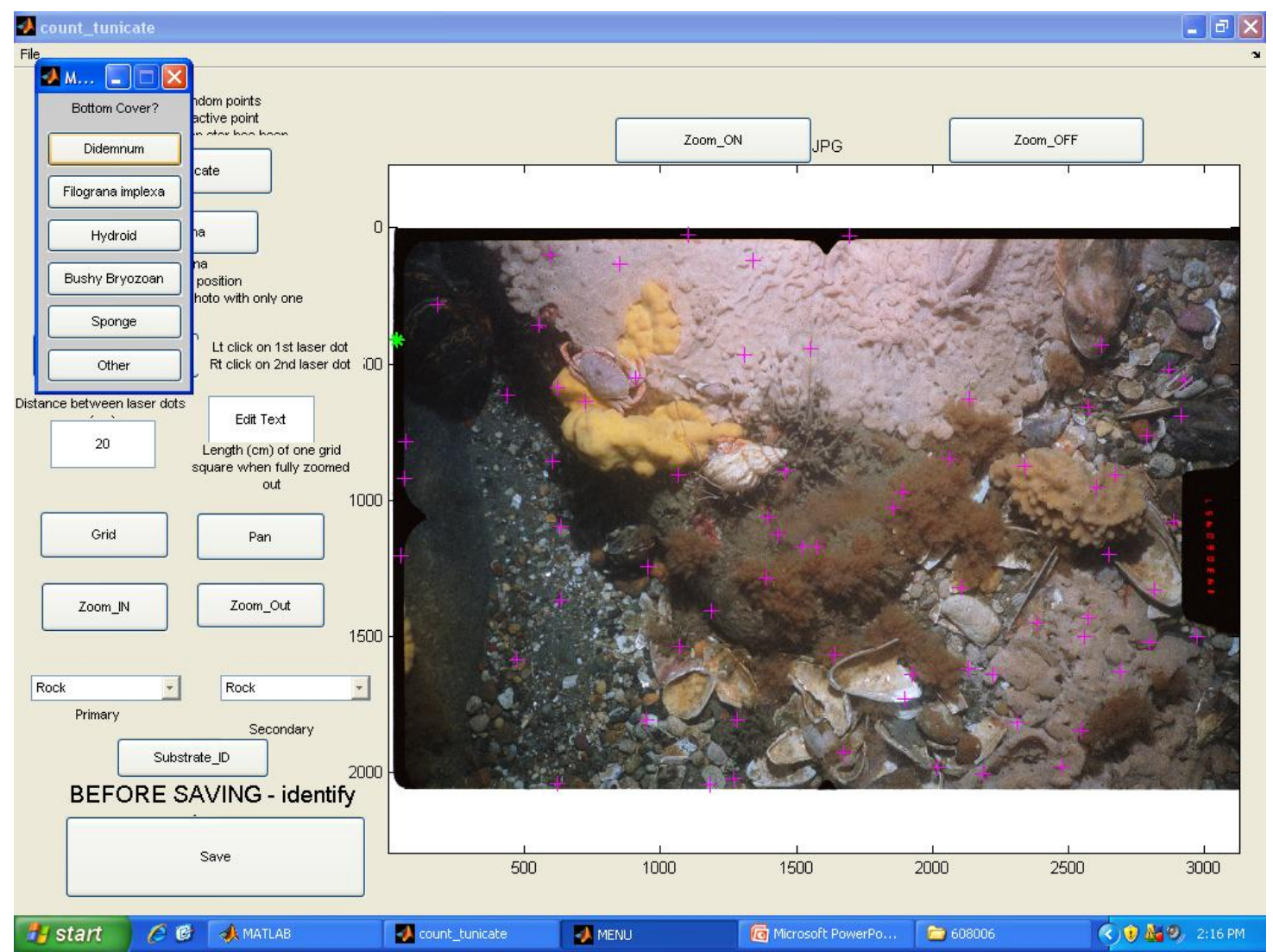

Figure 2. Screen shot of the Mathworks Matlab R2006a program used to analyze bottom photographs for the random-point method. 


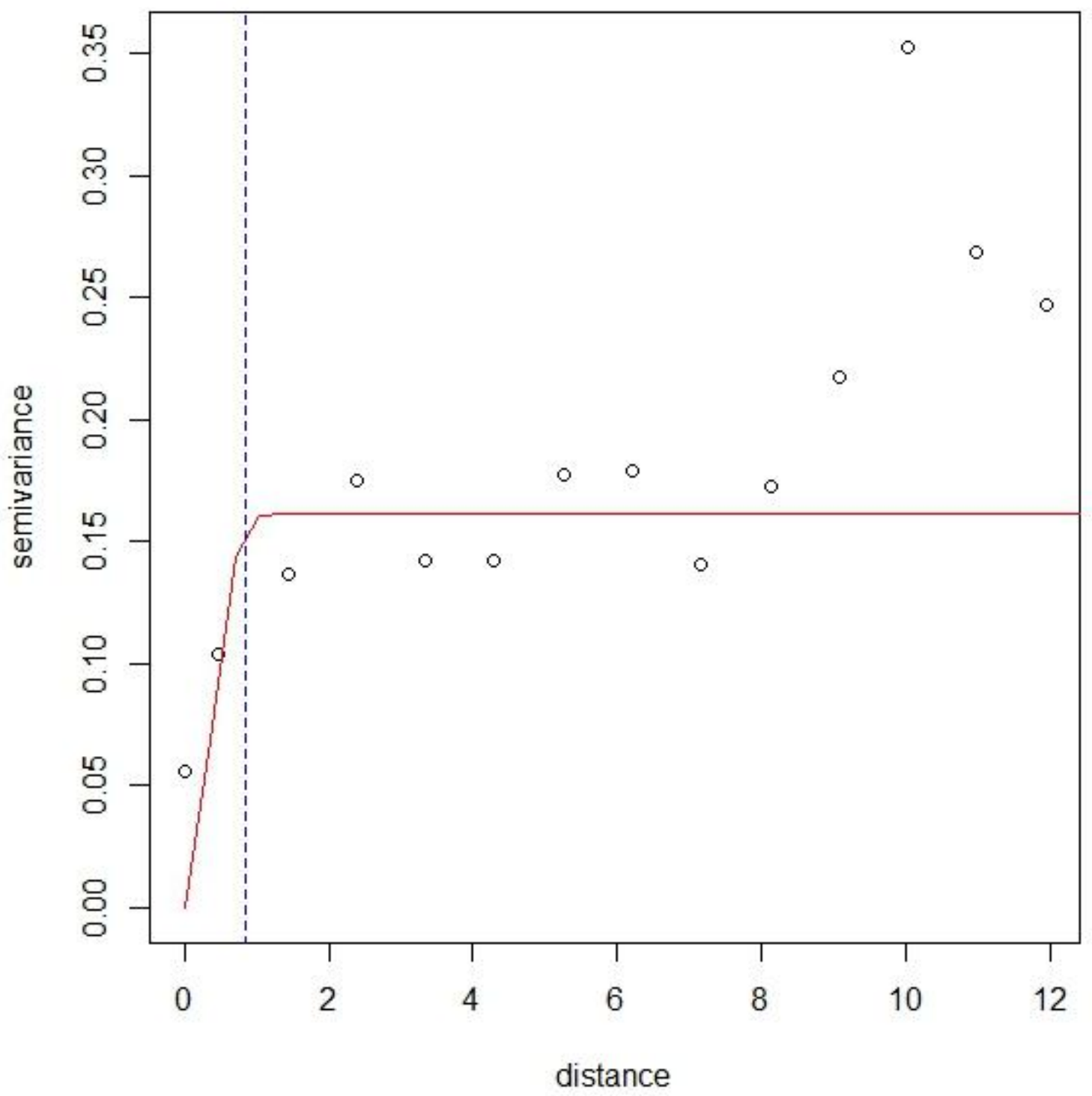

Figure 3. Variogram showing the distance at which autocorrelation exists among photographs. Distance is in kilometers and the vertical dashed line corresponds to the maximum transect length of $0.8 \mathrm{~km}$. 


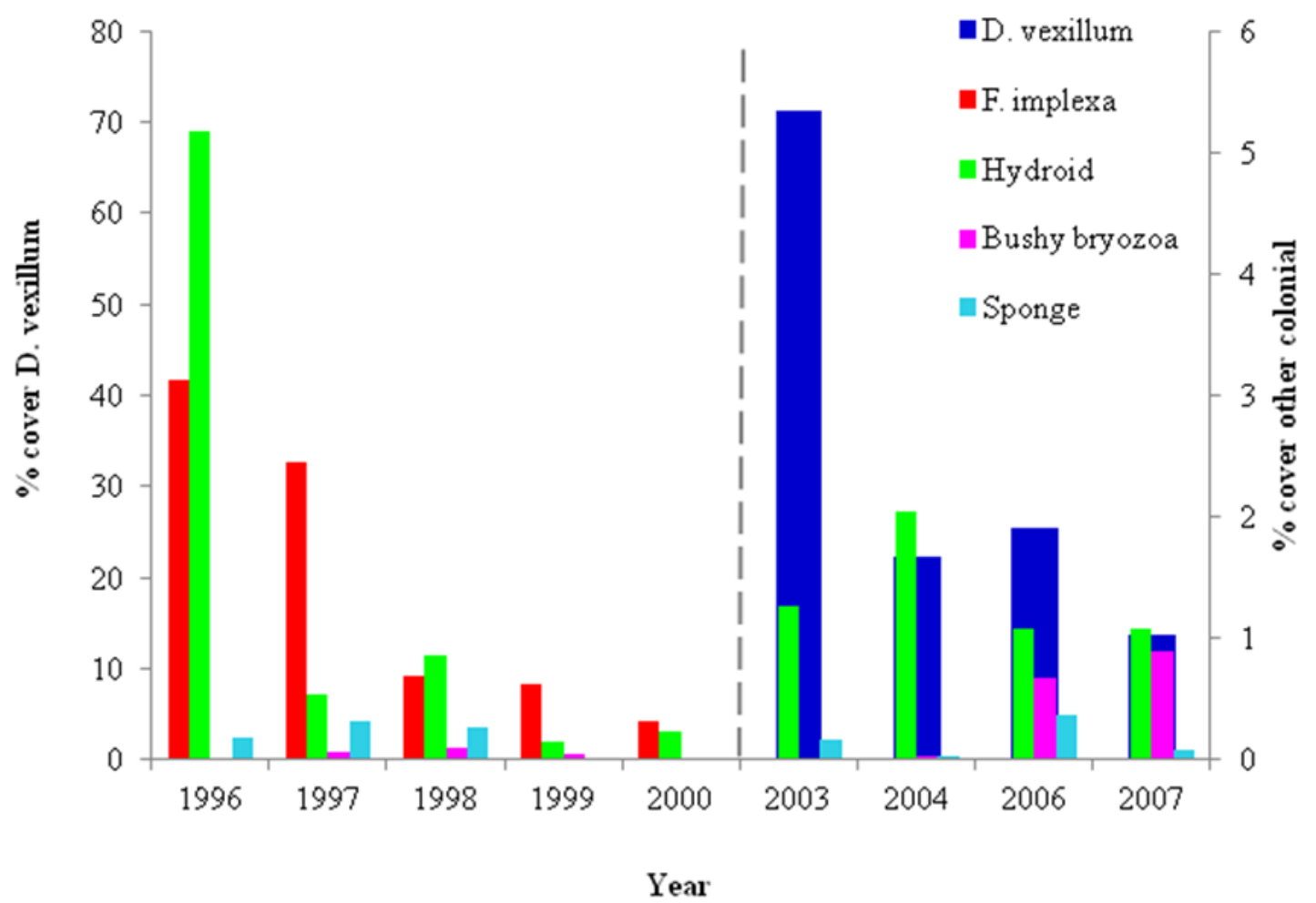

Figure 4. Percent cover of colonial epifauna taxa over time. The vertical dashed line indicates when the D. vexillum infestation began in Area 18. 


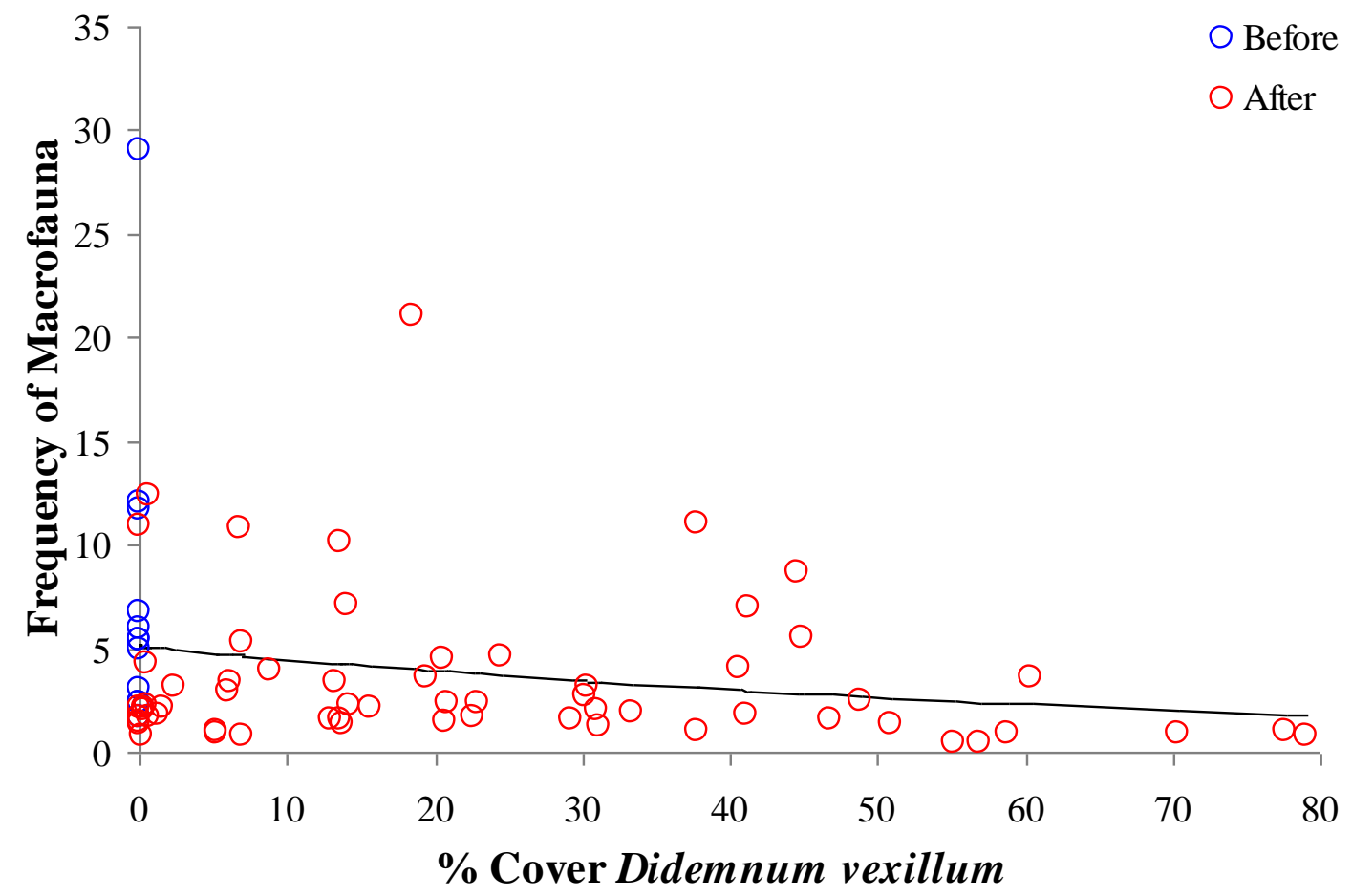

Figure 5. Relationship between the percent cover of $D$. vexillum and frequency of free-living macrofauna. The solid line is the fitted relationship from a GLM. 


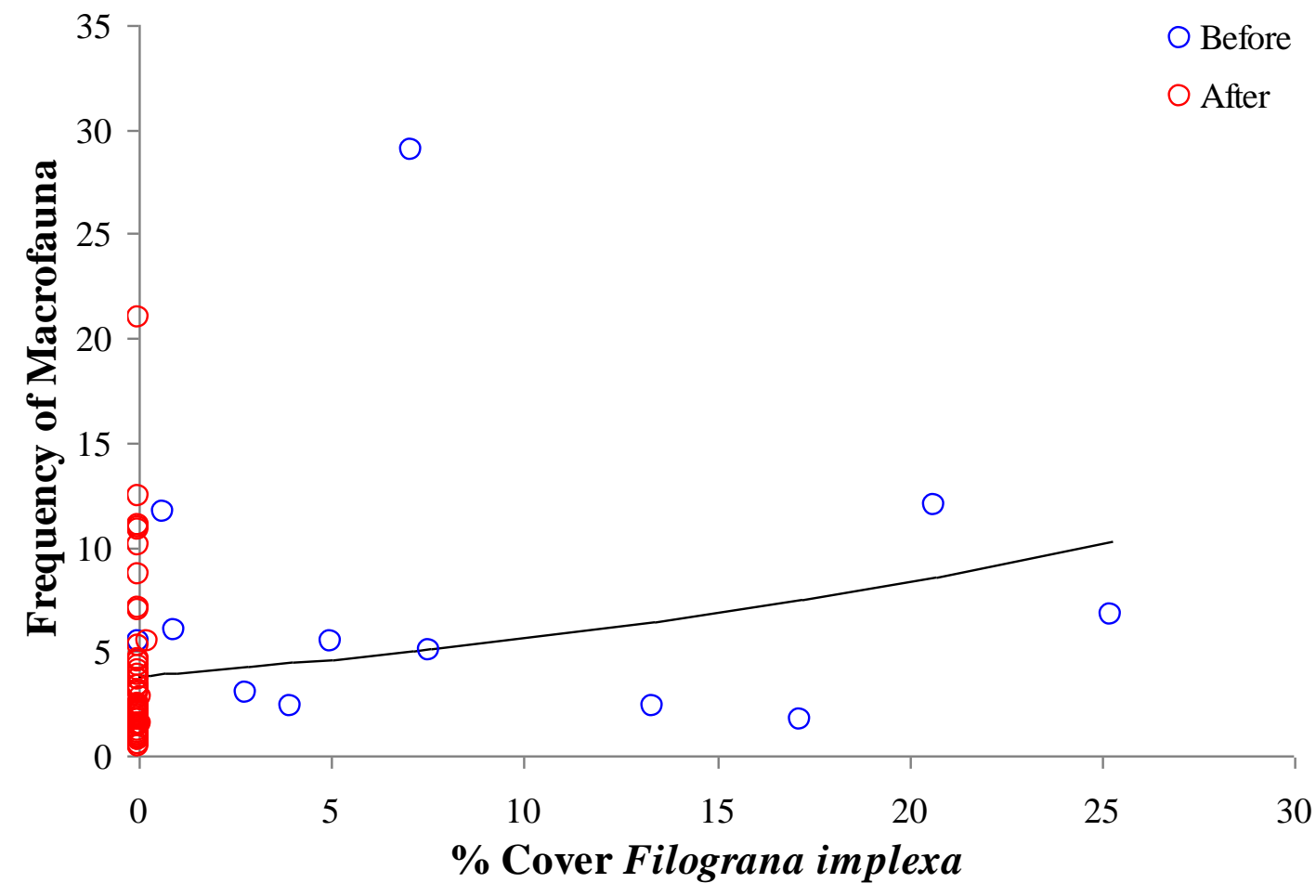

Figure 6. Relationship between the percent cover of $F$. implexa and frequency of freeliving macrofauna. The solid line is the fitted relationship from a GLM. 


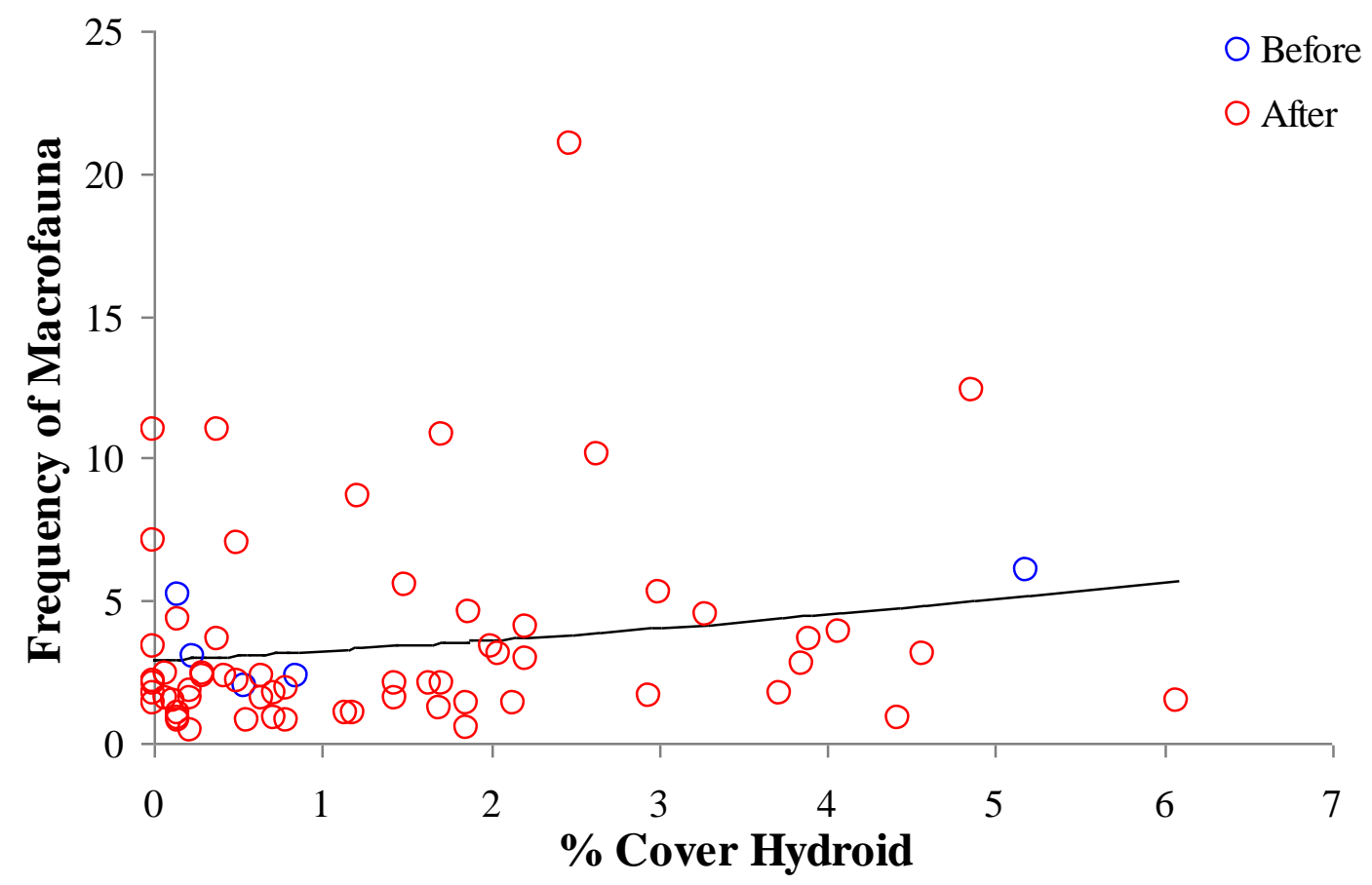

Figure 7. Relationship between the percent cover of hydroid and frequency of freeliving macrofauna. The solid line is the fitted relationship from a GLM. 


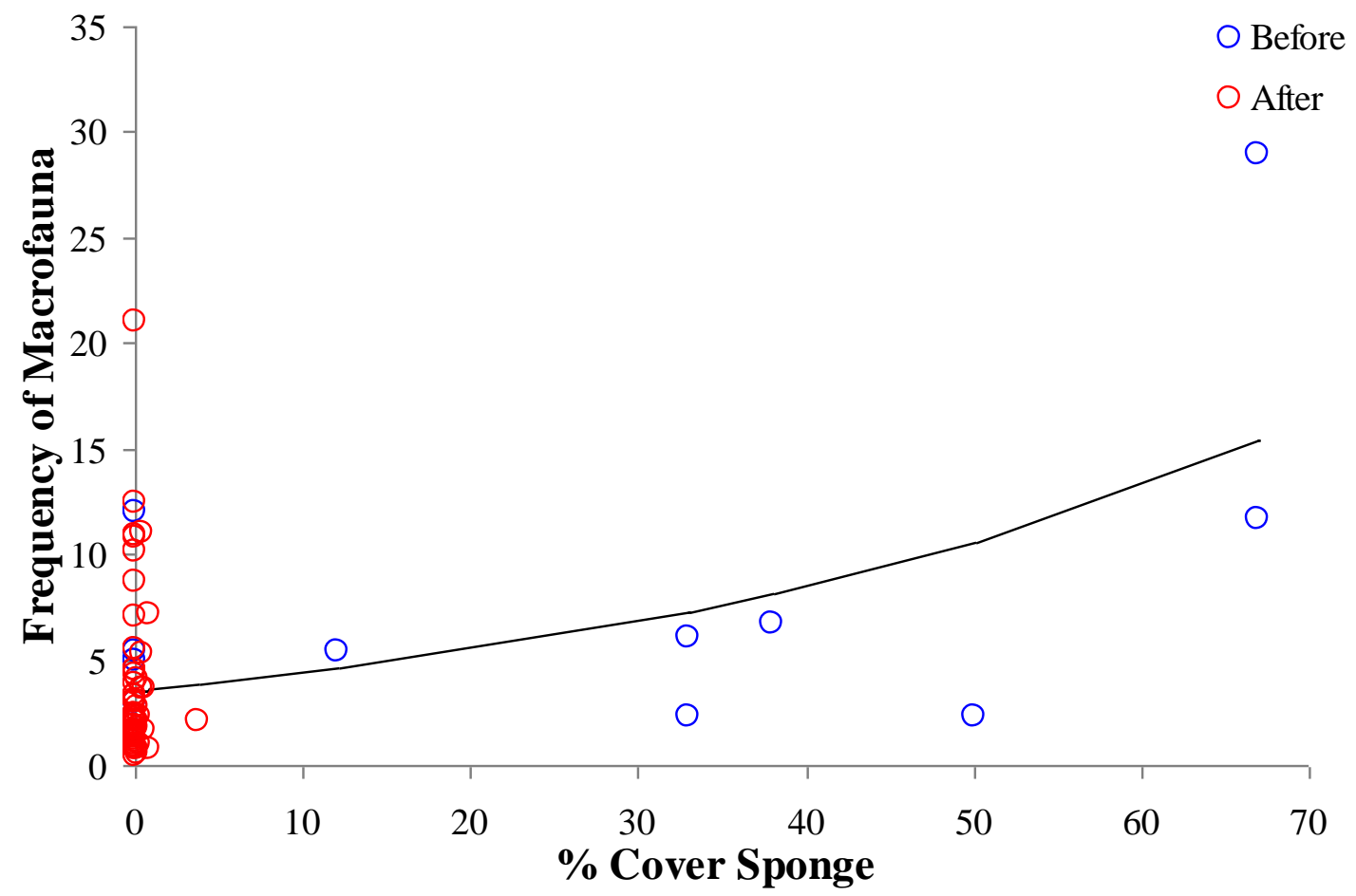

Figure 8. Relationship between the percent cover of sponge and frequency of freeliving macrofauna. The solid line is the fitted relationship from a GLM. 


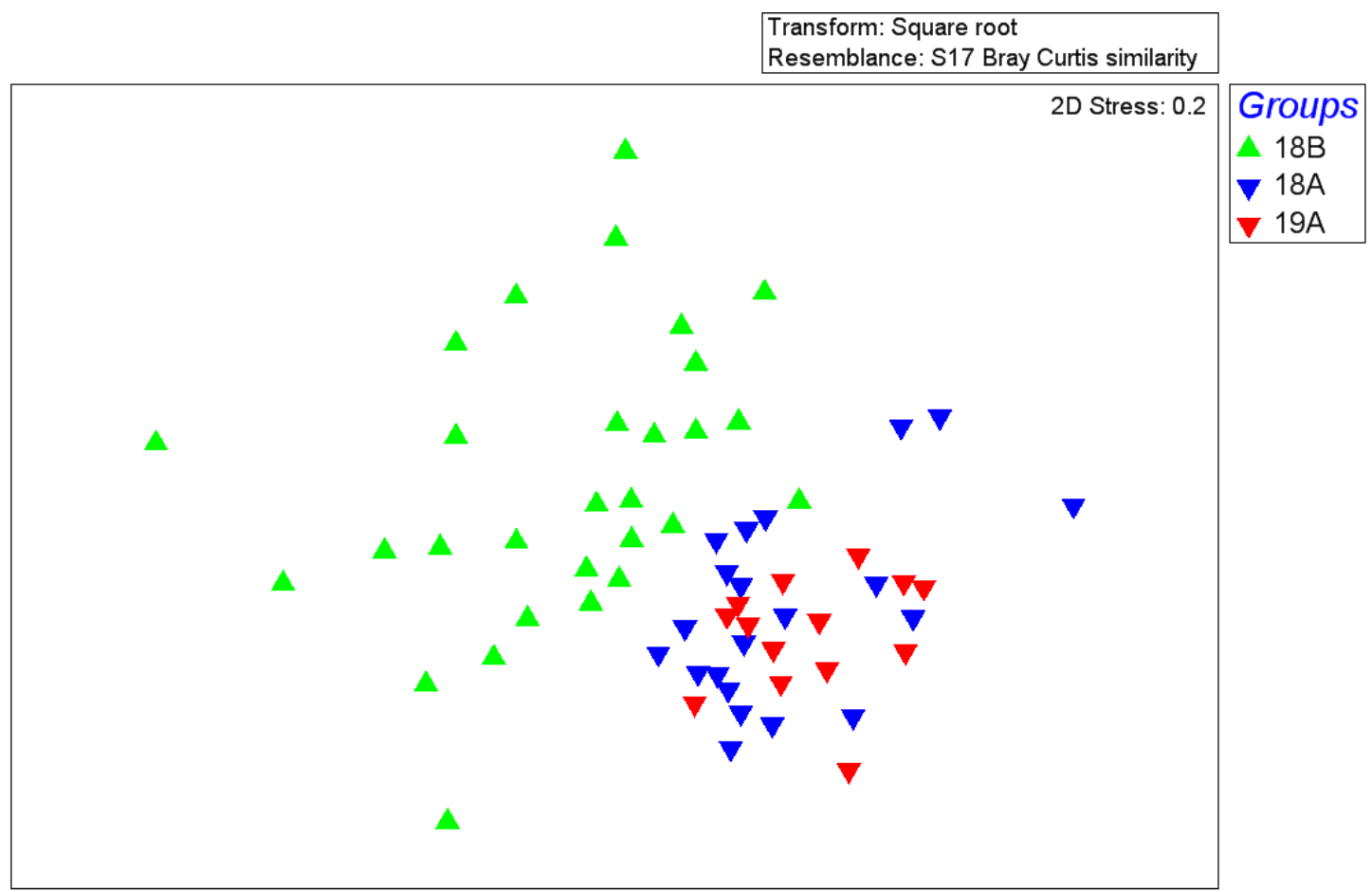

Figure 9. Non-metric Multi-Dimensional Scaling (MDS) plot based on the abundance data of 97 species in Naturalist dredge samples from Area 18 (open to fishing) and Area 19 (closed to fishing). Symbols correspond to Area 18 before the infestation of D. vexillum (18B) (1994-2000) and Areas 18 and 19 after the infestation of $D$. vexillum (18A, 19A) (2002-2008). 
a)

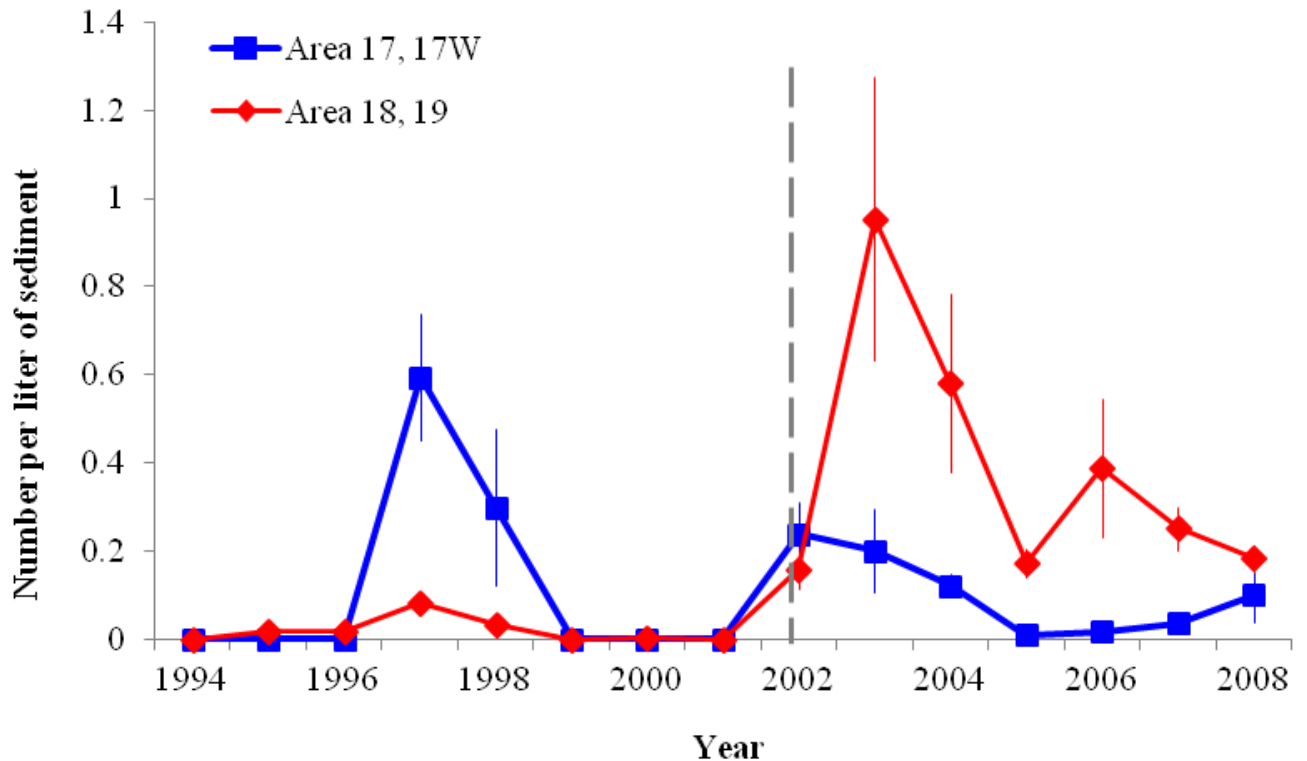

b)

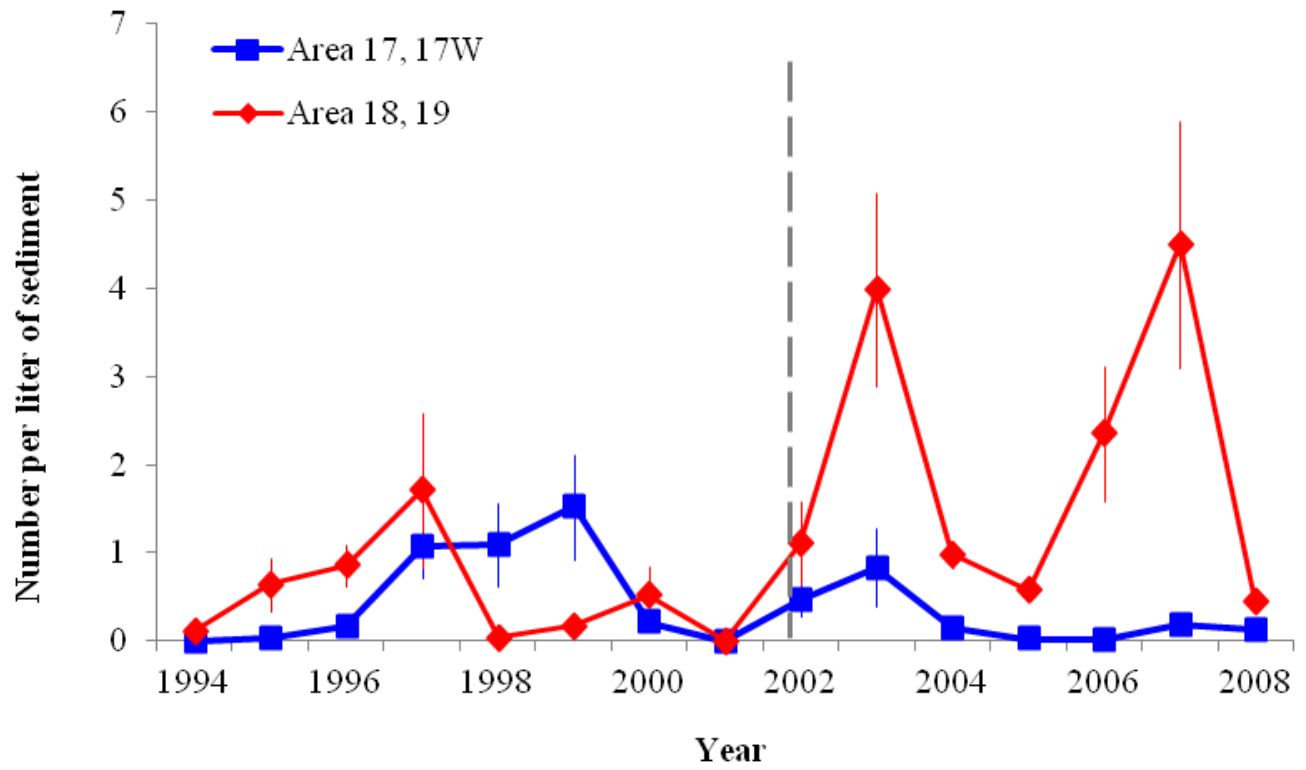

Figure 10. Number per liter of sediment of two polychaete species Harmothoe extenuata (a) and Nereis zonata (b) collected in Naturalist dredge samples from Areas 18 and 19 colonized by $D$. vexillum and Areas 17 and $17 \mathrm{~W}$ not colonized by $D$. vexillum. The vertical dashed lines indicate when the infestation of $D$. vexillum began. 


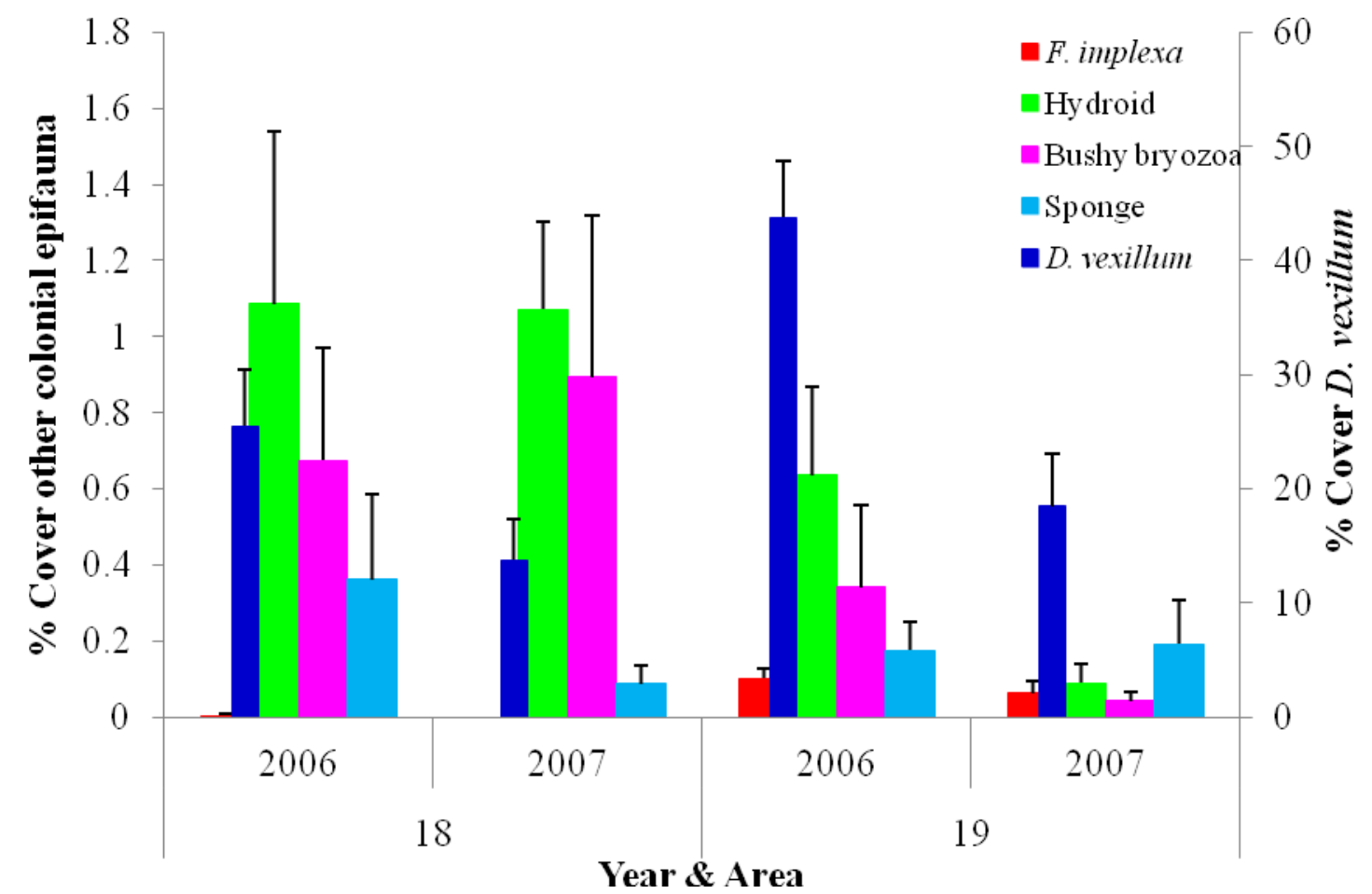

Figure 11. Percent cover of colonial epifauna in Areas 18 and 19 after the infestation of D. vexillum. 


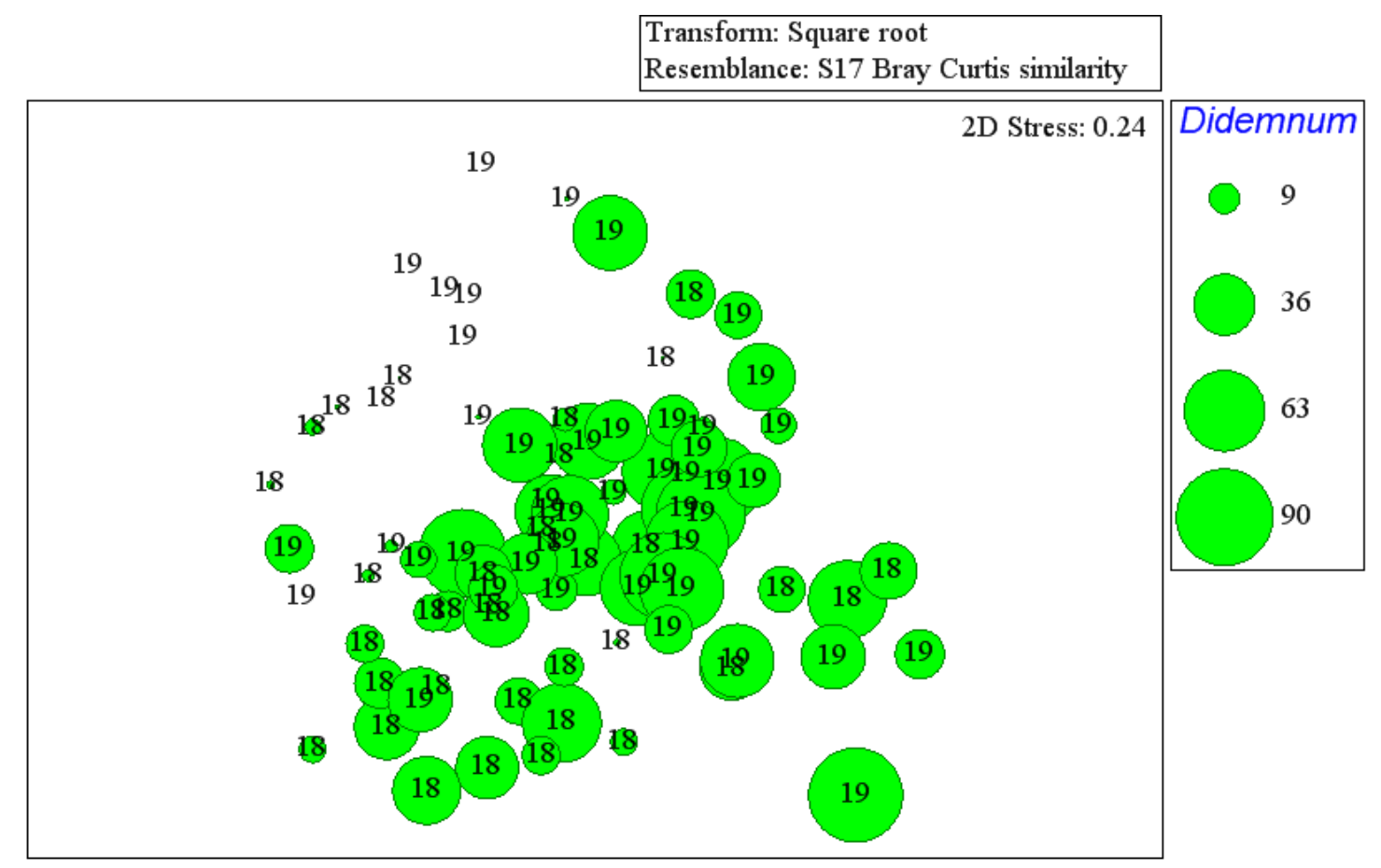

Figure 12. Non-metric Multi-Dimensional Scaling (MDS) plot showing the abundance of 18 benthic macrofaunal taxa in 82 photographic transects from Areas 18 and 19 in 2006 and 2007. The label identifies the area and the bubble size is proportional to the percent cover of $D$. vexillum. 


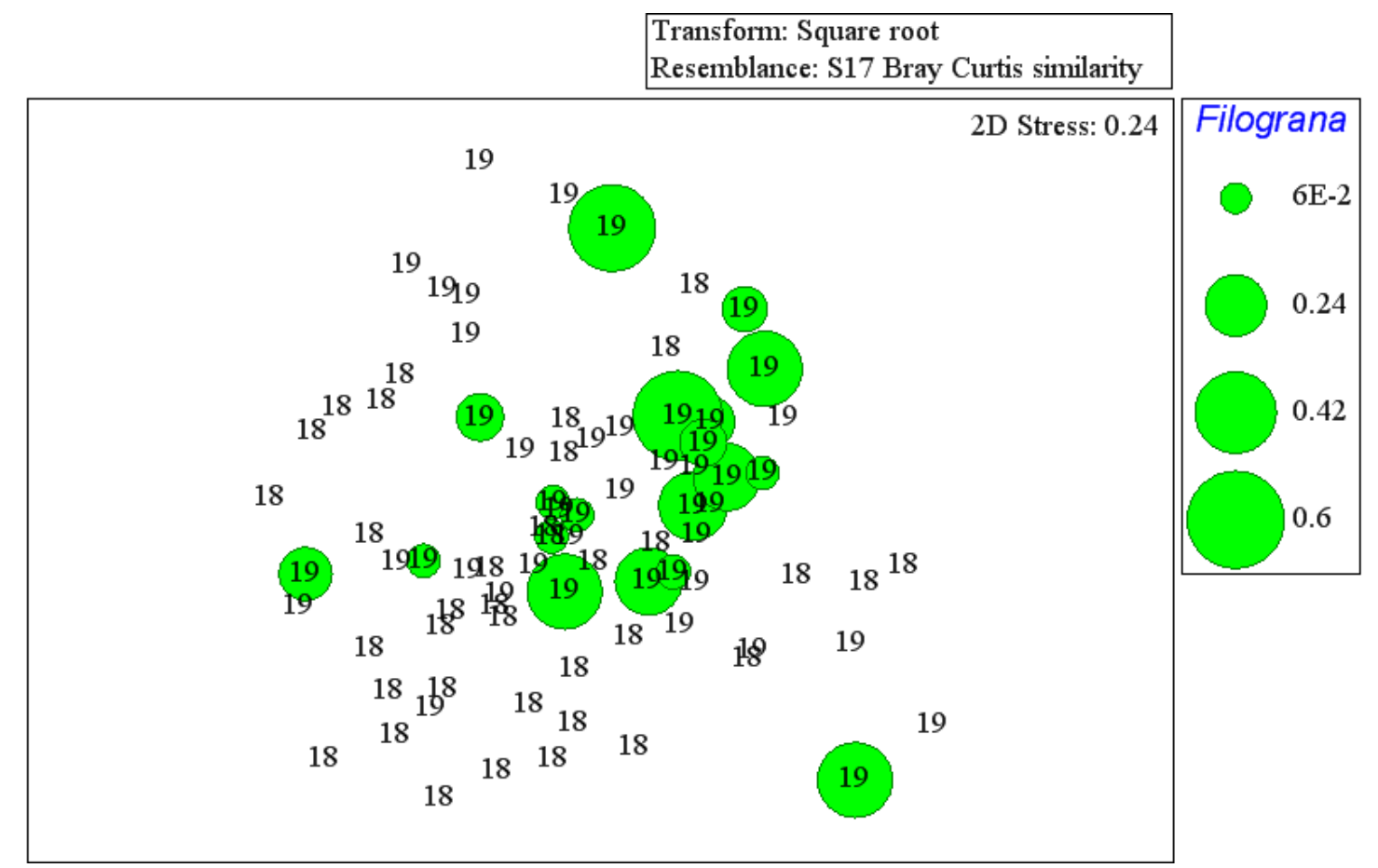

Figure 13. Non-metric MDS plot showing the abundance of 18 benthic macrofaunal taxa in 82 photographic transects from Areas 18 and 19 in 2006 and 2007. The label identifies the area and the bubble size is proportional to the percent cover of $F$. implexa. 


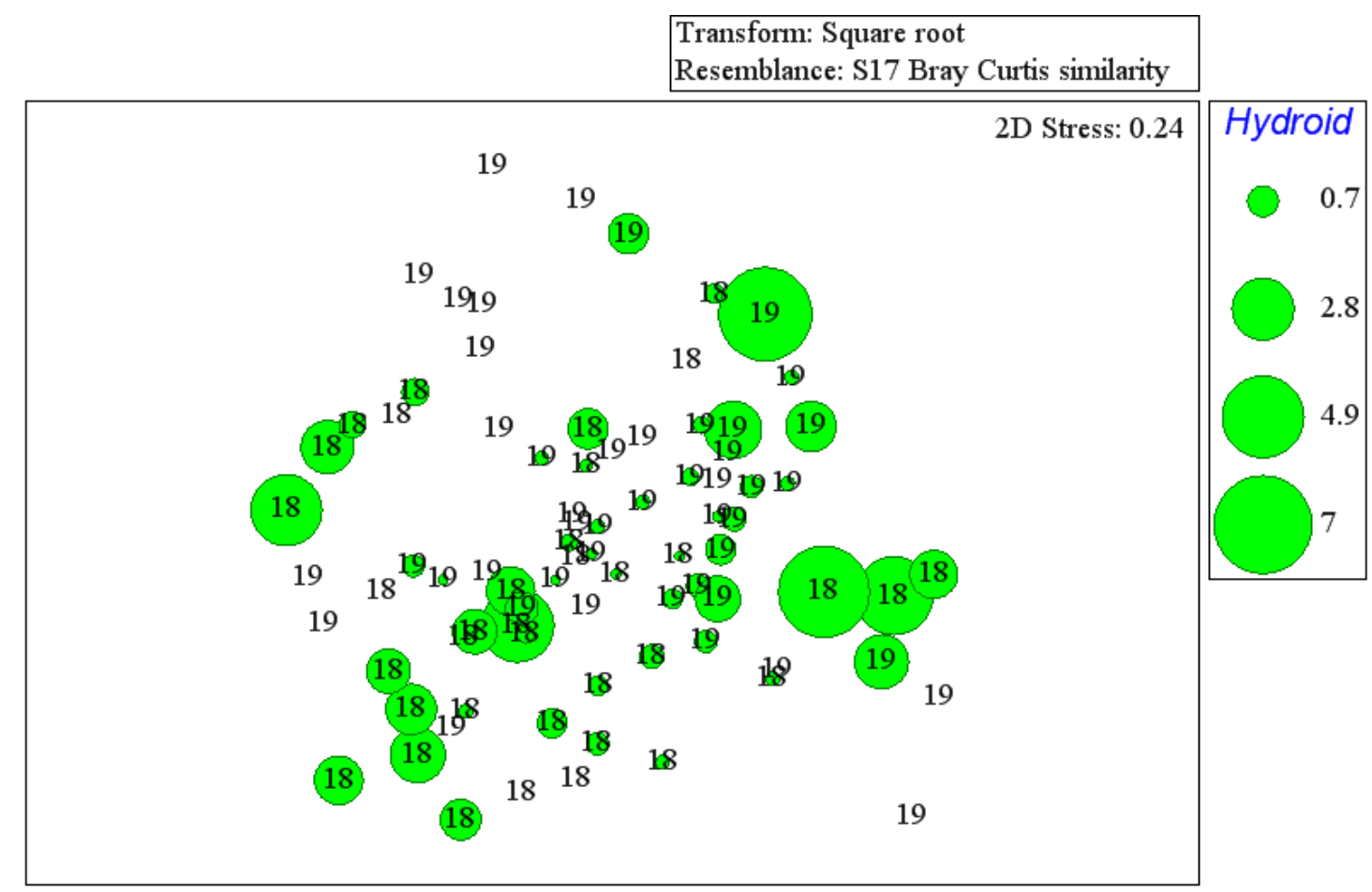

Figure 14. Non-metric MDS plot showing the abundance of 18 benthic macrofaunal taxa in 82 photographic transects from Areas 18 and 19 in 2006 and 2007. The label identifies the area and the bubble size is proportional to the percent cover of Hydroids. 


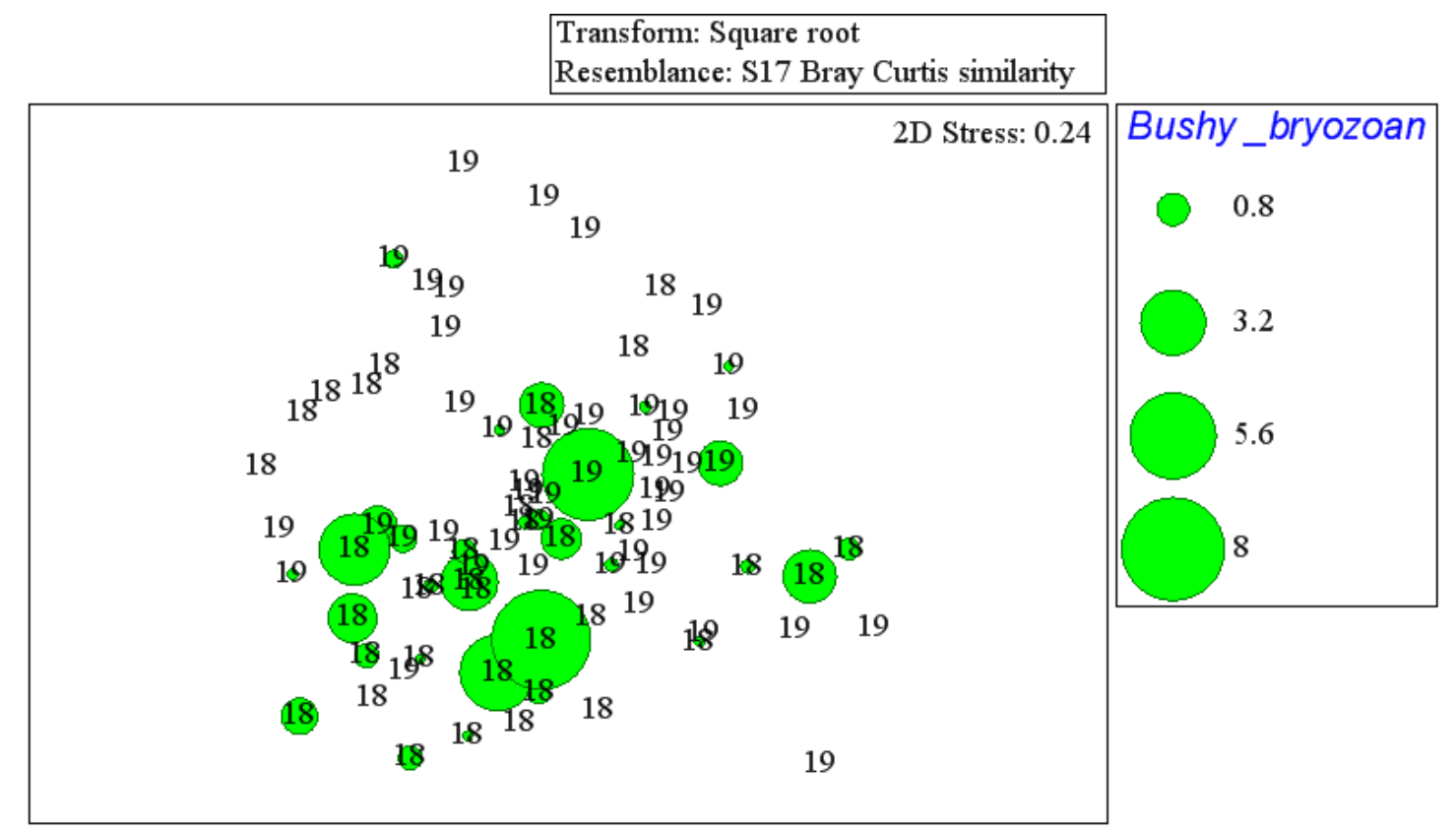

Figure 15. Non-metric MDS plot showing the abundance of 18 benthic macrofaunal taxa in 82 photographic transects from Areas 18 and 19 in 2006 and 2007. The label identifies the area and the bubble size is proportional to the percent cover of Bushy bryozoan. 


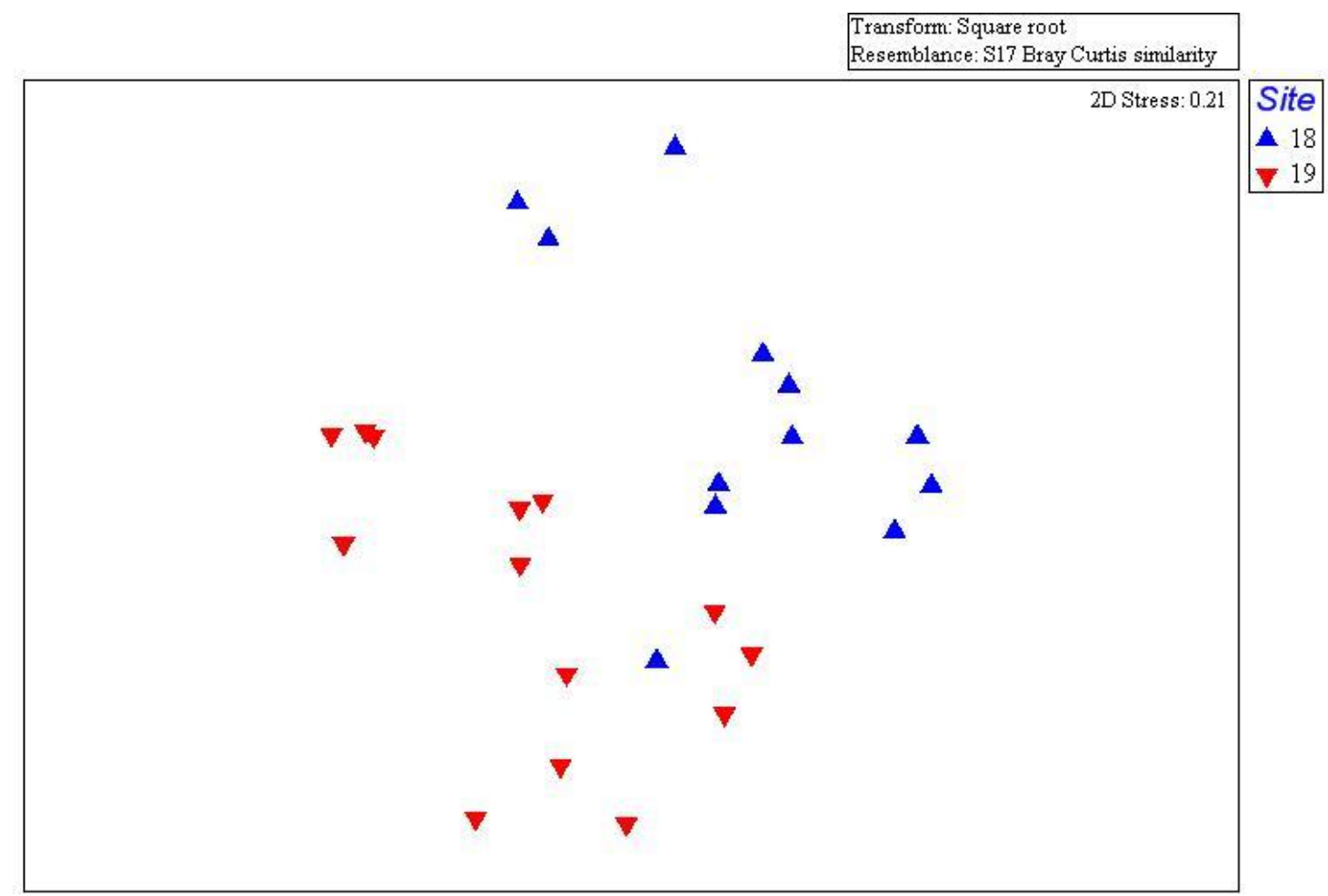

Figure 16. Non-metric Multi-Dimensional Scaling (MDS) plot based on the abundance data of 91species in Naturalist dredge samples from Area 18 (open to fishing) and Area 19 (closed to fishing) after the invasion of D. vexillum (2005-2008). 


\section{BIBLIOGRAPHY}

Asch RG, Collie JS (2008) Changes in a benthic megafaunal community due to disturbance from bottom fishing and the establishment of a fishery closure. Fishery Bulletin 106(4): 438-456

Backus RH (1987) Geology. In: Backus RH, Bourne DW (eds) Georges Bank, MIT Press, Massachusetts, USA, pp 22-24

Bax N, Williamson A, Aguero M, Gonzalez E, Geeves W (2003) Marine invasive alien species: a threat to global biodiversity. Marine Policy 27: 313-323

Blackwood D, Parolski K, Valentine P (2000) Seabed Observation and Sampling System: U.S. Geological Survey Fact Sheet FS-142-00

Bullard SG, Sedlack B, Reinhardt JF, Littly C, Gareau K, Whitlatch RB (2007) Fragmentation of colonial ascidians: differences in reattachment capability among species. Journal of Experimental Marine Biology and Ecology 342: 166-168

Collie JS, Escanero GA, Valentine PC (1997) Effects of bottom fishing on the benthic megafauna of Georges Bank. Marine Ecology Progress Series 155: 159-172

Collie JS, Escanero GA, Valentine PC (2000) Photographic evaluation of the impacts of bottom fishing on benthic epifauna. ICES Journal of Marine Science 57: 9871001

Collie JS, Hermsen J, Valentine P, Almeida F (2005) Effects of fishing on gravel habitats: assessment and recovery of benthic megafauna on Georges Bank. American Fisheries Society Symposium 41: 325-343

German AW (1987) History of the early fisheries, 1720-1930. In: Backus RH, Bourne DW (eds) Georges Bank, MIT Press, Massachusetts, USA, pp 409-424

Hart DR, Chute AS (2004) Essential fish habitat source document. Sea scallop, Placopecten magellanicus, life history and habitat characteristics. DIANE Publishing

Hennemuth RC, Rockwell S (1987) History of fisheries management and conservation. In: Backus RH, Bourne DW (eds) Georges Bank, MIT Press, Massachusetts, USA, pp 430-446

Hixon MA, Tissot BN, Pearcy WG (1991) Fish assemblages of rocky banks of the Pacific Northwest: Final Report (No. 52). US Dept. of the Interior, Minerals Management Service, Pacific OCS Region 
Jones JB (1992) Environmental impact of trawling on the seabed: a review. New Zealand Journal of Marine and Freshwater Research 26(1): 59-67

Kott, P (2002) A complex didemnid ascidian from Whangamata, New Zealand. Journal of the Marine Biological Association of the UK 82(4): 625-628

Lengyel NL, Collie JS, Valentine, PC (2009) The invasive colonial ascidian Didemnum vexillum on Georges Bank-Ecological effects and genetic identification. Aquatic Invasions 4(1): 143-152

Lodge DM, Williams S, MacIsaac HJ, Hayes KR, Leung B, Reichard S, Mack RN, Moyle PB, Smith M, Andow DA, Carlton JT, McMichael A (2006) Biological invasions: recommendations for US policy and management. Ecological Applications 16(6): 2035-2054

Mercer JM, Whitlatch RB, Osman RW (2009) Potential effects of the invasive colonial ascidian (Didemnum vexillum Kott, 2002) on pebble-cobble bottom habitats in Long Island Sound, USA. Aquatic Invasions 4(1): 133-142

Morris JA Jr, Carman MR, Hoagland KE, Green-Beach ER, Karney RC (2009) Impact of the invasive colonial tunicate Didemnum vexillum on the recruitment of the bay scallop (Argopecten irradians irradians) and implications for recruitment of the sea scallop (Placopecten magellanicus) on Georges Bank. Aquatic Invasions 4(1): 207-211

Murawski SA, Brown R, Lai HL, Rago PJ, Hendrickson L (2000) Large-scale closed areas as a fishery-management tool in temperate marine systems: the Georges Bank experience. Bulletin of Marine Science 66(3): 775-798

Smith BE, Collie JS, Lengyel NL (2013) Effects of chronic bottom fishing on the benthic epifauna and diets of demersal fishes on northern Georges Bank. Marine Ecology Progress Series 472: 199-217

Stefaniak L, Lambert G, Gittenberger A, Zhang H, Lin S, Whitlatch RB (2009) Genetic conspecificity of the worldwide populations of Didemnum vexillum Kott, 2002. Aquatic Invasions 4(1): 29-44

Stefaniak L, Zhang H, Gittenberger A, Smith K, Holsinger K, Lin S, Whitlatch RB (2012) Determining the native region of the putatively invasive ascidian Didemnum vexillum Kott, 2002. Journal of Experimental Marine Biology and Ecology 422: 64-71

Thouzeau G, Robert G, Smith SJ (1991) Spatial variability in distribution and growth of juvenile and adult sea scallops Placopecten magellanicus (Gmelin) on eastern Georges Bank (Northwest Atlantic). Marine Ecology Progress Series 74: 205-218 
Uchupi E, Austin JA Jr (1987) Morphology. In: Backus RH, Bourne DW (eds) Georges Bank, MIT Press, Massachusetts, USA, pp 25-30

Valentine PC, Carman MR, Blackwood DS, Heffron EJ (2007a) Ecological observations on the colonial ascidian Didemnum sp. in a New England tide pool habitat. Journal of Experimental Marine Biology and Ecology 342(1): 109-121

Valentine PC, Collie JS, Reid RN, Asch RG, Guida VG, Blackwood DS (2007b) The occurrence of the colonial ascidian Didemnum sp. on Georges Bank gravel habitat - Ecological observations and potential effects on groundfish and scallop fisheries. Journal of Experimental Marine Biology and Ecology 342(1): 179-181

Valentine PC, Carman MR, Dijkstra J, Blackwood DS (2009) Larval recruitment of the invasive colonial ascidian Didemnum vexillum, seasonal water temperatures in New England coastal and offshore waters, and implications for spread of the species. Aquatic Invasions 4(1) 153-168 